Article

\title{
Heavy Minerals as Indicators of the Source and Stratigraphic Position of the Loess-Like Deposits in the Orava Basin (Polish Western Carpathians)
}

\author{
Dorota Chmielowska $^{1, *}$ and Dorota Salata ${ }^{2}$ \\ 1 Institute of Geography, Pedagogical University of Krakow, Podchorążych 2, 30-084 Kraków, Poland \\ 2 Institute of Geological Sciences, Jagiellonian University, Gronostajowa 3a, 30-387 Kraków, Poland; \\ dorota.salata@uj.edu.pl \\ * Correspondence: dorota.chmielowska@up.krakow.pl
}

Received: 17 March 2020; Accepted: 14 May 2020; Published: 16 May 2020

\begin{abstract}
This study is focused on the loess-like deposits accumulated on glaciofluvial fans of the Czarny Dunajec River in the Orava Basin (Southern Poland). The deposition of these sediments took place during three cold intervals of the Pleistocene: Würm, Riss, and Günz/Mindel. So far, the provenance and age of the deposits has not been precisely defined, even though the development of each fan is believed to be related to the successive glacial periods in the Tatra Mountains. Heavy minerals were studied to determine the source of the deposits. Heavy mineral analyses revealed that zircon, tourmaline, rutile, garnet, amphibole, epidote, and apatite are the typical constituents of the heavy mineral fraction. Abundances of heavy minerals differ in each of the Pleistocene fans of the Czarny Dunajec River, especially the amphibole content. However, the chemical composition of garnet, amphibole, and tourmaline is rather uniform. This research showed that mainly medium-grade metamorphic rocks with a subordinate share of high-grade metamorphics, and granitic rocks are the dominant source rocks of the deposits studied. Such rocks are exposed in the Western Tatra Mountains, which most probably supplied the Orava Basin with clastic material. Change in abundances of heavy minerals in the succession may reflect the progressive erosion of the source area. Grain-size distribution and textural features of the sampled sediments suggest fluvial and aeolian modes of transportation. Additionally, this study indicated that heavy minerals may be used to correlate the loess covers in the Orava Basin.
\end{abstract}

Keywords: heavy minerals; loess-like deposits; glaciofluvial fan; Orava Basin; Western Tatra Mountains

\section{Introduction}

Heavy minerals are commonly used to track the sources of deposits and transport directions, reconstruct depositional environments, recognize the paleogeography of the source area or types of post-sedimentary processes affecting the sediments [1].

Loess-deposits cover one-tenth of the earth's surface [2-4], recording important information on the paleoatmospheric patterns and climate change (e.g., [5-13]). One of the fundamental problems posed by loess deposits is the identification of their potential source areas. It is believed that this is the first step toward understanding how the production of the dust fraction took place, its incorporation in the transport mode, transport and depositional conditions [2]. However, dust from different source areas may be homogenized in the atmosphere, causing serious problems with the identification of individual source areas [2,14-16]. In addition, determining the composition of heavy mineral assemblages in loess is important for places where, theoretically, material supply seems to be limited by orographic barriers 
such as intramontane basins, river valleys, or similar localities, but where the geology of the catchment area is relatively complex.

One of such examples are the loess-like deposits of unknown provenance located in the Orava Basin in the Polish Western Carpathians. Geological, geomorphological, and paleogeographic studies conducted in the Orava Basin (e.g., [17-28]) have reported the presence of loess-like deposits in fluvial gravel fans, without indicating their source or age, even when each gravel horizon is chronologically associated with one of the successive glaciations in the Tatra Mountains [29].

Furthermore, the age and spatial extent of individual glaciofluvial fans of the Czarny Dunajec River are not precisely defined. The stratigraphic subdivision of these fans, related to subsequent glaciations in the Tatra Mountains, has been based, so far, on their position in relation to the present-day channel position of the Czarny Dunajec River, as well as the local lithological composition, degree of weathering and cementation of the gravel deposits $[17,22,25,26]$. A new chronostratigraphic subdivision of the Quaternary sediments and river terraces in the Orava Basin based on OSL dating was proposed by Olszak et al. [30,31], but it applies only to deposits of the latest glaciation.

Glaciofluvial gravels in the fans of the Czarny Dunajec River consist mainly of clasts of crystalline rocks from the Western Tatra Mountains [17,18,22,23,27,32]. The 1-3.5 m thick, loess-like sediments covering them were deposited during three cold periods of the Pleistocene: Würm, Riss, and Günz/Mindel, and are the youngest lithostratigraphic units present in the area [33].

Contrary to the source of glaciofluvial material, the origin of grains in the aeolian loess-like deposits remains unknown since no studies on their composition and source have been conducted so far. It is thus interesting whether the material of the fine-grained sediments is derived only from the crystalline rocks of the Western Tatra Mountains or also from other mountain ranges, mainly built of flysch deposits, that surround the Orava Basin from the north.

This research was mainly aimed at the comparison of the heavy mineral composition of the loess-like deposits from three different Pleistocene levels in the Orava Basin and the determination of the source area(s) of the deposits. We have also tested whether heavy minerals may be a useful tool for the correlation and identification of these sediments.

\section{Study Area}

\subsection{Geological Structure and Relief}

The Orava Basin constitutes the western part of the intramontane Orava-Nowy Targ Basin in southern Poland. It lies at the boundary between two blocks: the Central Carpathians and the Outer Carpathians [27,28,34-40] (Figure 1). The basin surface area is ca. $362 \mathrm{~km}^{2}$. The Orava Basin is drained by the Czarny Dunajec River belonging to the Baltic Sea drainage system.

Geologically, the Orava Basin is a tectonic depression superimposed on three tectonic units of various age and geological history: The Pieniny Klippen Belt (Jurassic-Eocene rocks), the Magura Nappe (Cretaceous-lower Miocene flysch), and the Podhale Flysch (Eocene-Oligocene) [27,28,34-44] (Figure 2).

The relief of the Orava Basin is composed of a series of extensive and flat Pleistocene fans and Holocene terraces of the Czarny Dunajec River, dipping gently $\left(3-5^{\circ}\right)$ to the north. Three glaciofluvial covers may be distinguished in the western part of the basin, at: $800-750 \mathrm{~m}$ a.s.l., $750-635 \mathrm{~m}$ a.s.l., and 635-615 m a.s.l. and these are correlated with the Tatra glaciations, the highest with the Günz/Mindel, the middle one with the Riss, and the lowest with the Würm (Figure 1). In Polish literature, the terms used for the Tatra glaciations are equivalents of the Alpine glaciations: Günz, Mindel, Riss, and Würm [29]. With regard to modern stratigraphy, they correspond to the following Marine Isotope Stages (MIS): Günz corresponds to MIS 21 to MIS 13; Mindel is commonly correlated with two different marine isotope stages, MIS 12 and MIS 10; the Riss is paralleled by MIS 6, 8 and 10, while the Würm is correlated with MIS 2-5d [45-47]. A Late Glacial alluvial fan located at altitudes of 750-600 $\mathrm{m}$ a.s.l. is present in the eastern part of the Orava Basin $[22,23,25]$ (Figure 1). The bottom of the present-day river 
channel lies at altitudes between $600 \mathrm{~m}$ a.s.l. (northern part of the basin) and $700 \mathrm{~m}$ a.s.1. (southern part of the basin).

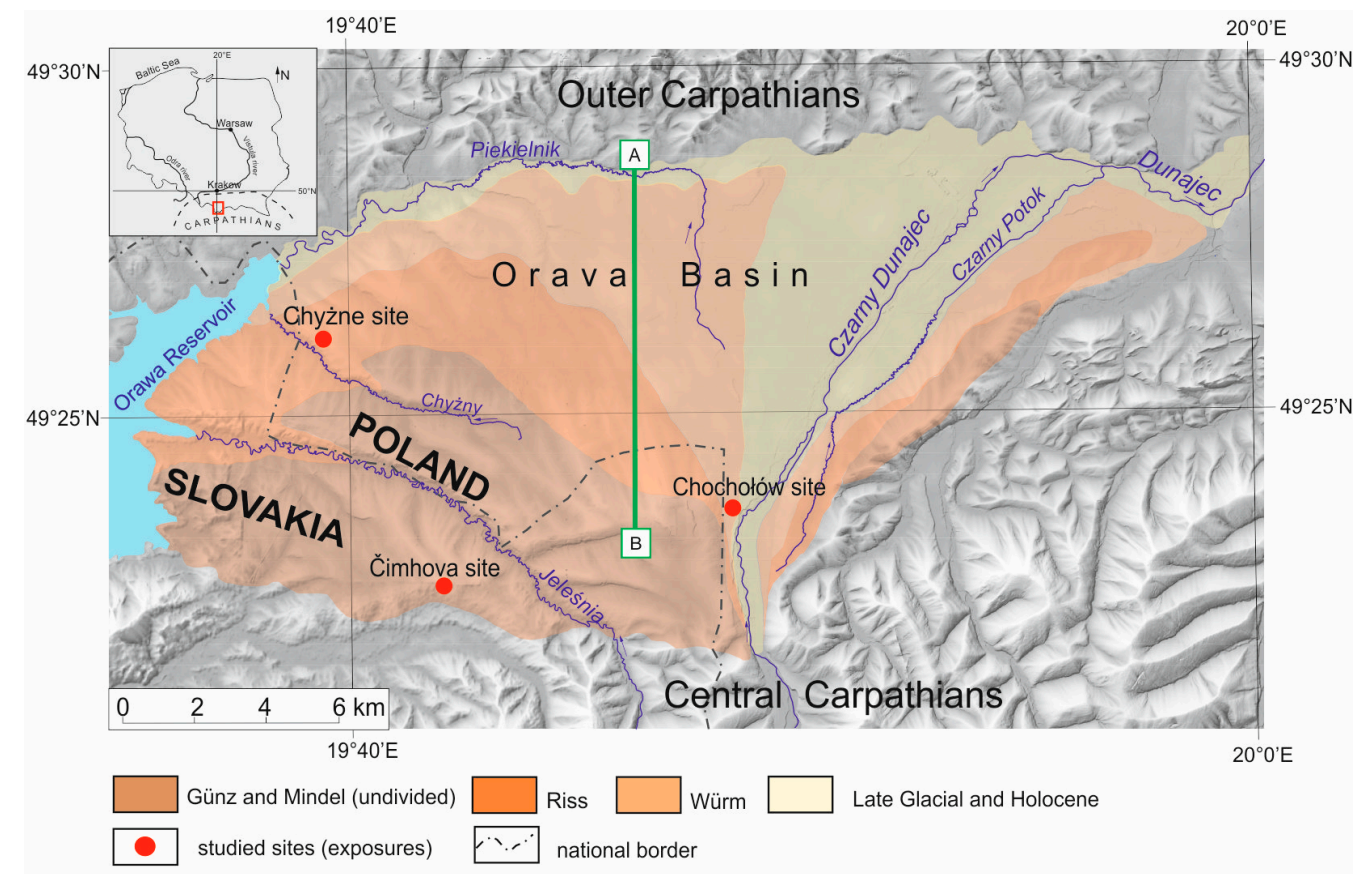

A
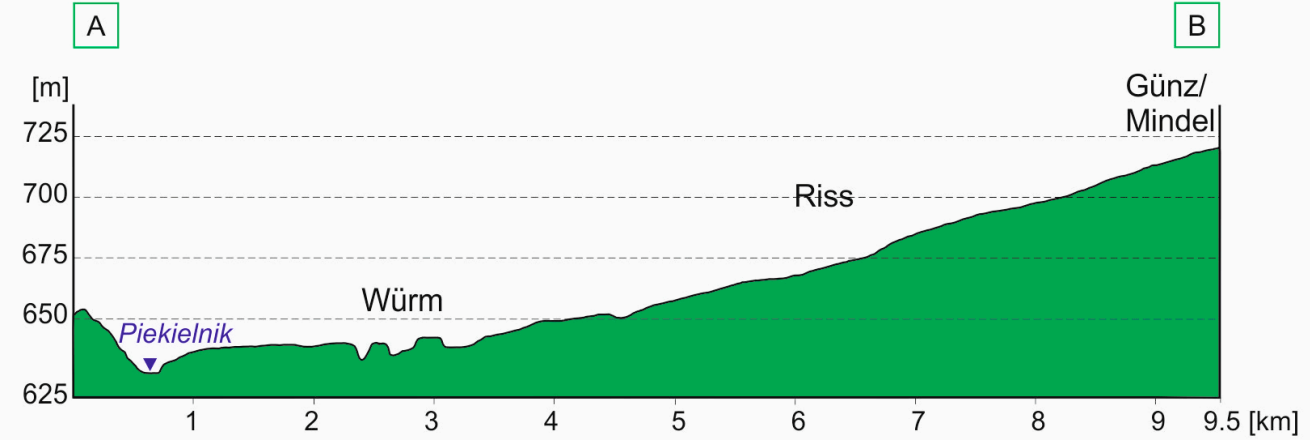

Figure 1. Sediment sampling location and cross-section through the glaciofluvial fans of the Czarny Dunajec River in the Orava Basin (age and extent of fans after Watycha [22,23], Baumgart-Kotarba [25], and Chmielowska and Woronko [33]).

\subsection{Source Areas}

The Orava Basin may be sourced from several directions, however the most important source areas are located to the south (within the Central Carpathians) and to the north (within the Outer Flysch Carpathians). The Tatra part of the Central Carpathians is built of igneous rocks (granitoids), Paleozoic metamorphic rocks (gneisses, crystalline schists, amphibolites), and Mesozoic sedimentary rocks (mainly carbonates) [39,48-50]. Mesozoic (mainly limestones and marls) and Paleogene (sandstones and shales) sedimentary rocks compose the Pieniny Klippen Belt [20]. Between the Tatra Mountains and the Pieniny Klippen Belt, folded and overthrusted Mesozoic rocks are overlain by a synclinorium built of sandstone-shale series representing the Podhale Flysch (Eocene-Oligocene) [51] (Figure 2). The Outer Carpathians are situated to the north of the Pieniny Klippen Belt, mostly in the region covered by the Beskidy Mountains ranges. They are mainly built of Upper Jurassic to lower Miocene flysch deposits, which are folded and overthrusted as a series of stacked nappes (e.g., [51,52]). The Magura Nappe covers the largest area and lies adjacent to the Pieniny Klippen Belt. It was folded between the Eocene [53] and the Miocene [54,55] (Figure 2). 


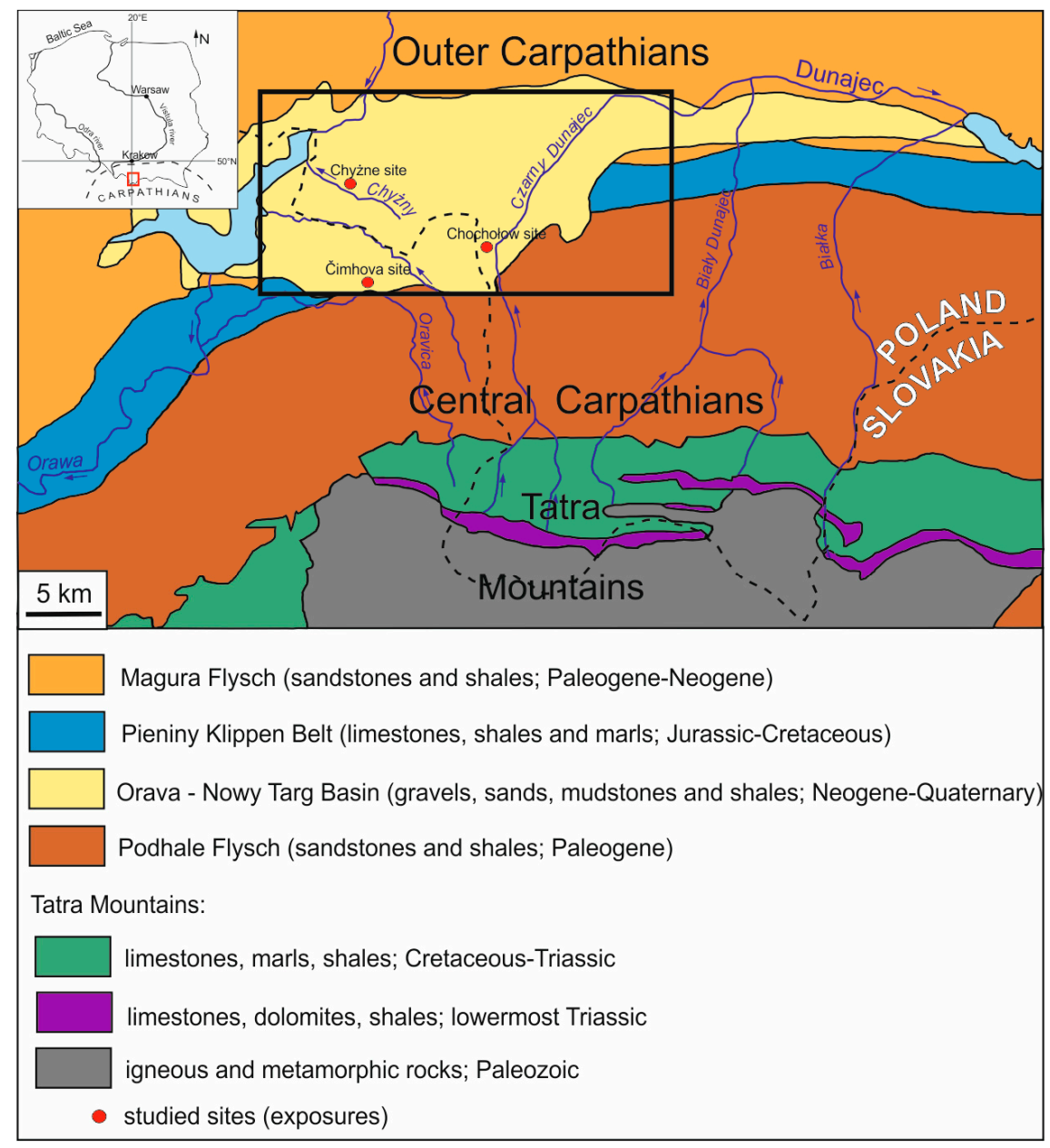

Figure 2. Geological sketch-map of the Orava-Nowy Targ Basin with studied sites, after Tokarski et al. [44].

The Orava Basin is filled with Neogene freshwater sediments (fluvial and lacustrine) composed mostly of clays with lignite intercalations, conglomerates with a clay and sand matrix, gravels and sands $[21-23,26,38,55,56]$. These sediments are arranged in several sedimentary cycles. Their total thickness reaches up to $1300 \mathrm{~m}$ [22,23,32]. Neogene sediments are unconformably overlain by Pleistocene strata. These were deposited in the basin by the Czarny Dunajec River flowing from the Western Tatra Mountains. Generally, glaciofluvial sediments (gravels and sands) from glacial intervals and proglacial lacustrine clays from interglacial intervals were deposited in the axial part of the basin [21]. The maximum thickness of these sediments $(112 \mathrm{~m})$ was noted in a borehole in the northern part of the basin, thinning out to the south (from $30 \mathrm{~m}$ to $6 \mathrm{~m}$ ) [21-23,32]. Lithological identification of clasts in gravels from the individual fans revealed two sources of glaciofluvial clastics: (i) The Tatra Mountains-crystalline and sedimentary rocks from this area clearly dominate in number and volume, and (ii) the hills region (Podhale Flysch) — present in subordinate amounts as flysch clasts; moreover, clasts of the latter location are present only within the youngest terraces and the youngest fan (Würm Glaciation and the Holocene) $[22,23,26,44]$. The majority of the sediments are derived from the Central Carpathian area (Tatra Mountains, Podhale Flysch trough, Pieniny Klippen Belt) $[21-23,28,55,56]$ (Figure 2).

\subsection{Composition of Clasts from Glaciofluvial Fans of the Czarny Dunajec River Levels}

The oldest sediments from the Günz/Mindel glaciations form the topmost fan. These are difficult to distinguish on the surface $[18,24,26,57]$; only in the Czarny Dunajec borehole they are separated by interglacial clays [32]. Gravels from the terminal part of the Mindel Glaciation and the beginning of the 
new interglacial (500-400 ka) attain the maximum thickness in the borehole log [22-24]. Laterally, their thickness varies between 2 to $15 \mathrm{~m}$; coarse-grained quartzite clasts ( $\mathrm{Mz} 16-32 \mathrm{~mm}$ ) predominate in their petrographic composition (more than 70\%) $[18,26]$. These also include granite clasts (up to $25 \%$ ), heavily weathered and easily decomposing to clay, and quartz-feldspar grains with mica (so-called granite groats). Vein quartz clasts are present as an admixture (up to 5\%) [26] (Figure 3).

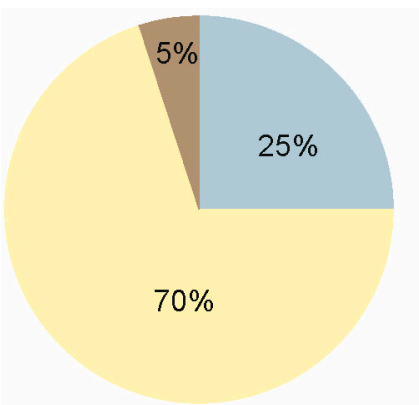

Günz/Mindel (Čimhova site)

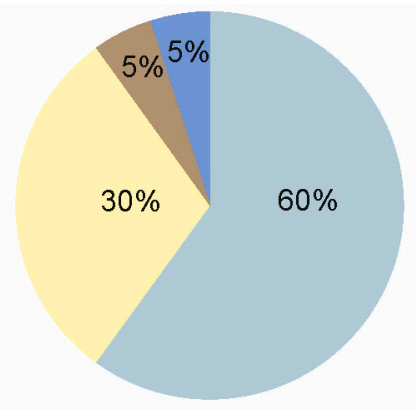

Riss (Chyżne site)

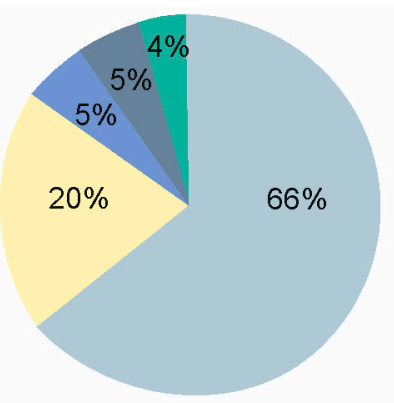

Würm (Chochołów site)

$\square$ granitoids $\square$ quartzites $\square$ vein quartz $\square$ gneisses $\square$ mica schists $\square$ limestones, dolomites and sandstones

Figure 3. Petrographic composition of gravels in the glaciofluvial fans of the Czarny Dunajec River, after Kukulak [26].

The middle fan was deposited during the Riss Glaciation (300-150 ka). These sediments are composed of coarse-grained clasts and gravels chaotically embedded in sand. The clasts decrease in size upwards and the material seems to be mostly (ca. 95\%) derived from the Tatra Mountains [22]. The contribution of quartzite clasts (up to $30 \%$ ) is lower than in the older sediments, while the proportion of granites, locally only slightly weathered, increases up to $60 \%$ [26]. Gneiss and vein quartz clasts complete their composition. Their contribution in the fan from the Riss Glaciation is up to $5 \%$ [26] (Figure 3). The thickness of gravels in this fan varies between 3 and $10 \mathrm{~m}$ [22].

Clasts in the sediments of the last Tatra glaciation, Würm (115-11.5 ka), form the youngest fan. They mainly include granite (ca. $66 \%$ ), quartzite (ca. $20 \%$ ), gneiss (ca. $5 \%$ ), and mica (ca. $5 \%$ ), and in smaller amounts limestone, dolostone, and flysch (ca. 4\%) $[23,26]$ (Figure 3). The predominance of slightly weathered granite clasts is highlighted. Gravels in the Würm fan become sandier upwards and pass locally into clayey sands with fine pebbles. They are covered by a continuous horizon of loess-like deposits that were deposited, according to Watycha [23], at the decline of the last glaciation (Dryas - Alleröd). The thickness of the whole series in this fan increases northwards from $5-10 \mathrm{~m}$ to $26 \mathrm{~m}$. The OSL age of the higher terrace $(9.5 \mathrm{~m})$ in Chochołów was determined at $46.5 \pm 3.9 \mathrm{ka}$, which is within Marine Isotope Stage 3 (MIS 3) [30].

The top cover of each Pleistocene fan of the Czarny Dunajec River constitutes loess-like deposits, in which the proportion of the silt fraction (63-4 $\mu \mathrm{m}$ according to the Udden-Wenthworth grain scale $[58,59])$ is significant ( $41 \%$ on the average, up to $82.3 \%)[33,60]$. The thickness of the loess-like deposits locally varies between $1 \mathrm{~m}$ and $3.5 \mathrm{~m}(1.5-2.0 \mathrm{~m}$ on the average) $[22,23,25,33]$.

Regardless of their age, the fans covered by silty sediments are always similar in structure. They include laminated silty-sandy sediments, forming Fm $->$ FSm rhythmites or massive silts (Fm). Massive silts (Fm) occur on the flat top surfaces of the fans. Laminated sediments (FSh) are present mainly in the fans from the Günz/Mindel and Würm glaciations [33]. The loess-like deposits directly overlie gravels with clasts $33 \mathrm{~mm}$ to $128 \mathrm{~mm}$ in size on the average and massive sandy gravels (Gm, GSm). Initial stages of weathering are discernible in the basal parts of the analyzed sections in the form of clays rich in highly weathered granite clasts, while the top parts contain silts homogenized by weathering [33]. The absolute age of the loess-like deposits has not been determined yet. TL-dating of two clay samples near Chyżne (Riss fan) $(146 \pm 40 \mathrm{ka}$ and $110 \pm 15 \mathrm{ka})$ suggests that they may be of 
Pleistocene age [25]. The upper age limit of the loess-like deposits may be indicated by conventional radiocarbon ages of the peat base (the oldest at $8960 \pm 80 \mathrm{BP} ;[61,62]$ ) in the peat bogs situated directly on the deposits studied.

\section{Material and Methods}

Material for the heavy mineral analyses was collected from the loess-like deposits in three study sites (Chochołów, Chyżne, and Čimhova) representing three glaciofluvial fans of the Czarny Dunajec in the Orava Basin, each corresponding to a different age (Figure 1). The sampled material was unconsolidated sediment. A total of 19 samples were analyzed, collected in vertical sections of natural exposures of the alluvial fans along the Czarny Dunajec River valley. In each exposure, material was collected from each recognized lithofacies. When there was no mesoscopically visible change in sediment in vertical section (massive structure), the samples were collected every $10-20 \mathrm{~cm}$ along the section.

The grain size analysis was carried out using a dry sieving (for grains coarser than $63 \mu \mathrm{m}$ ) and laser diffraction using Fritsch's laser particle analyzer Analysette 22 (for grains finer than $63 \mu \mathrm{m}$ ) [33]. The parameters used to describe the grain-size distribution such as: average size, sorting, skewness, median, kurtosis, and mode were obtained according to the Folk and Ward method [63] and the method of moments using Gradistat 5.11pl software [64]. Values of statistical parameters are presented in phi unit. All parameters and content of each fraction of loess-like deposits were calculated based on data from Chmielowska and Woronko [33].

The clastic material was cleaned with water to remove clay particles and sieved. Because of poor sorting, fraction distribution and different skewness between the sampled sites, a narrow fraction range of $0.06-0.10 \mathrm{~mm}$ was used for heavy mineral separation, which eliminates the effects of hydraulic sorting. This fraction best represented the heavy mineral distribution and allowed to make comparative analyses between the sampled sites. Heavy minerals were separated by the gravity method using sodium polytungstate with a $2.9 \mathrm{~g} / \mathrm{cm}^{3}$ density. Optical analysis was carried out on grain mounts in Canada balsam in two rounds according to the ribbon method [65]. To obtain statistically representative frequencies of transparent minerals, at least 300, non-micaceous, non-carbonate grains were counted in the first round. In the second round, 300 opaque and transparent mineral grains were counted to obtain the relative proportion of these two mineral groups (Table S1).

Zircon morphology was determined in three samples from each terrace based on counting of at least 100 grains in each sample in reference to the visual scale of Powers [66].

The chemical composition of garnet, tourmaline, and amphibole grains was studied in polished and carbon-coated grain mounts using a Cameca SX-100 electron microprobe (EMP) operating in a wavelength dispersion (WDS) mode, at the Joint-Institute Analytical Complex for Minerals and Synthetic Substances of the University of Warsaw. WDS analytical conditions were as follows: $15 \mathrm{kV}$ accelerating voltage, $20 \mathrm{nA}$ beam current and a focused beam. The following, synthetic and natural mineral standards were used for calibration: $\mathrm{Si}, \mathrm{Ca}$ and $\mathrm{Mg}$ (diopside), $\mathrm{Al}$ (orthoclase), $\mathrm{Cr}\left(\mathrm{Cr}_{2} \mathrm{O}_{3}\right)$, $\mathrm{Ti}$ (rutile), $\mathrm{Fe}\left(\mathrm{Fe}_{2} \mathrm{O}_{3}\right), \mathrm{Mn}$ (rhodonite), and $\mathrm{Na}$ (albite). Single-spot analyses were performed in the centers of the grains.

The contents of B, H and Li were not measured in tourmaline grains. Instead, they were calculated using stoichiometric constraints, assuming B $=3$ apfu (atoms per formula unit), $\mathrm{OH}+\mathrm{F}=4 \mathrm{apfu}$, $\mathrm{Li}=15-(\mathrm{T}+\mathrm{Z}+\mathrm{Y})$ and that all iron is $\mathrm{Fe}^{2+}$. The structural formula calculations were normalized to 31 anions. The calculation method ignores oxy-tourmaline species and causes that the exact contents of non-measured elements and accordingly the calculated cation amounts are not precise (especially $\mathrm{Li}_{2} \mathrm{O}$ and $\mathrm{H}_{2} \mathrm{O}$ amounts are likely overestimated), however the obtained results are sufficient for the provenance interpretations of the sediments (e.g., $[67,68])$. The amphiboles were classified by applying the Amphibole Classification Excel Spreadsheet [69], following the set of recommendations by Hawthorne et al. [70]. Probabilities for garnet source rocks were calculated using the formulas provided by Tolosana-Delgado et al. [71]. 


\section{Results}

\subsection{Grain-Size Distribution}

In the Chochołów site, the grain-size distribution is polymodal and characterized by negative skewness and poor or very poor sorting (Table 1). Silt-size grains dominate with the mean content of $48.4 \%$. The content of the sand fraction is $27.5 \%$, clay $-16.3 \%$ and gravel $-7.6 \%$ (Figure 4 ). The proportion of sand and gravel fractions diminishes toward the base of the section, respectively from $31.17 \%$ and $15.3 \%$ (Choch_1. depth $0.2 \mathrm{~m}$ ) to $26.1 \%$ and 6.2\% (Choch_6. depth $1.3 \mathrm{~m}$ ). Furthermore, the content of silt-size grains increases from $41.4 \%$ at the top to $47.9 \%$ at the base (Figure 4 ).
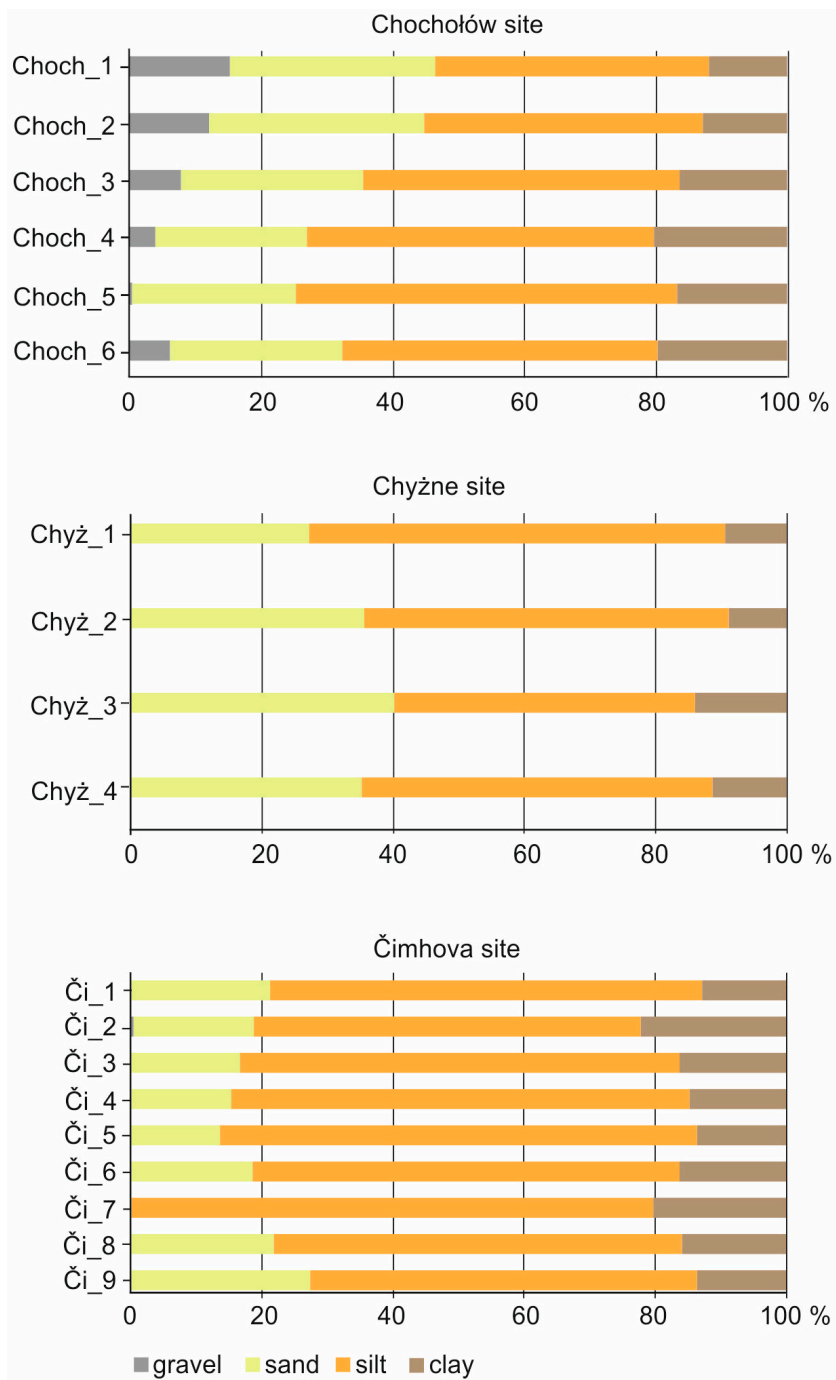

Figure 4. Grain-size composition of the loess-like deposits in study sites. Data on the content of each fraction are from Chmielowska and Woronko [33]. 
Table 1. Statistical grain-size parameters (Folk \& Ward method [63] and method of moments) of loess-like deposits in the study sites.

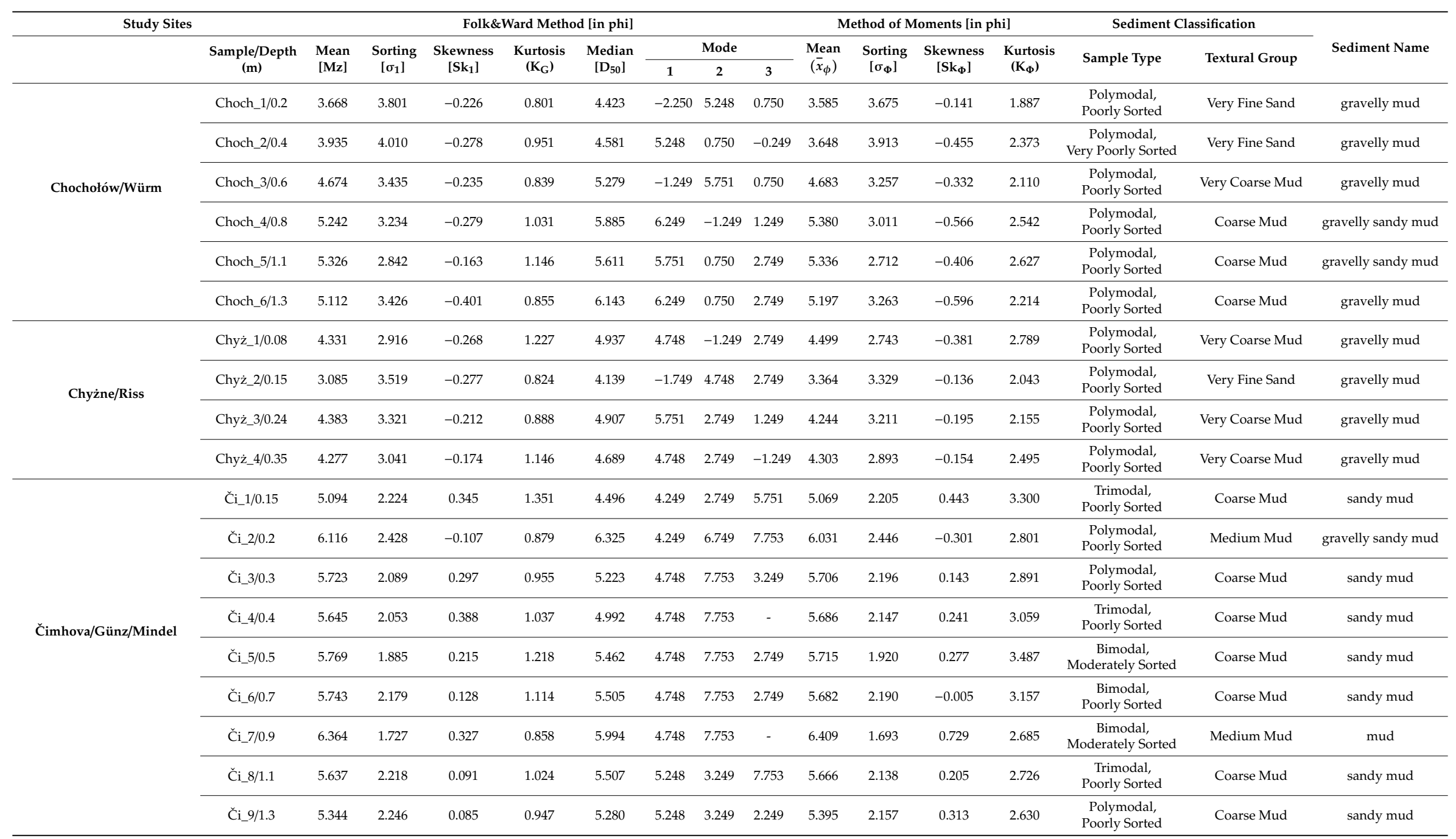


The loess-like deposits in the Chyżne site are characterized by poor sorting and negative skewness of the grain-size distribution. The sediments have polymodal grain-size distribution (Table 1). Silt-size grains predominate with a mean content of $48.9 \%$, while the mean content of the sand fraction is $30.8 \%$ and of clay fraction $-9.7 \%$. The proportion of the silt fraction changes from $59.8 \%$ at the top to $49.9 \%$ at the base in favor of sand from $25.5 \%$ at the top to $32.9 \%$ at the base of the section (Figure 4 ).

In the loess-like deposits of the Čimhova site, the grain-size distribution is polymodal and they have positive skewness, with the exception of sample Či_2 (depth $0.2 \mathrm{~m}$ ), where this parameter is negative. Furthermore, sample Či_6 (depth $0.7 \mathrm{~m}$ ) the skewness values is negative for method of moments but for graphical method is positive (Table 1). The value of the mean size (Mz) slightly varies in section and the loess-like deposits in the Čimhova site are characterized by poor sorting (Table 1). The silt fraction predominates with the average value of $66.3 \%$. The mean contribution of the additional fractions is $17 \%$ for sand and $16.1 \%$ for clay. The contribution of silt-sized grains decreases toward the base from $65.7 \%$ (depth $0.15 \mathrm{~m}$ ) to $58.9 \%$ (depth $1.3 \mathrm{~m}$ ). In turn, the content of the sand fraction slightly increases downwards (Figure 4).

\subsection{Heavy Mineral Data}

Zircon, tourmaline, rutile, garnet, hornblende, epidote, and apatite are present in all samples. Sillimanite, staurolite, chlorite, chromium spinel, monazite, and brookite are much less abundant or occur in trace quantities (Figure 5 and Table 2). Within each species, irregularly broken, rounded, and euhedral grains are present, especially when zircon, tourmaline (Figure 6A-D), and garnet are considered. Several stages of advanced corrosion are visible on hornblende and garnet (Figure 6E-G). Some apatite grains display corrosion, indicating slightly acidic conditions (Figure $6 \mathrm{H}$ ). Corrosion and various shapes of minerals are typical for all studied terraces regardless the depth at which they occur.

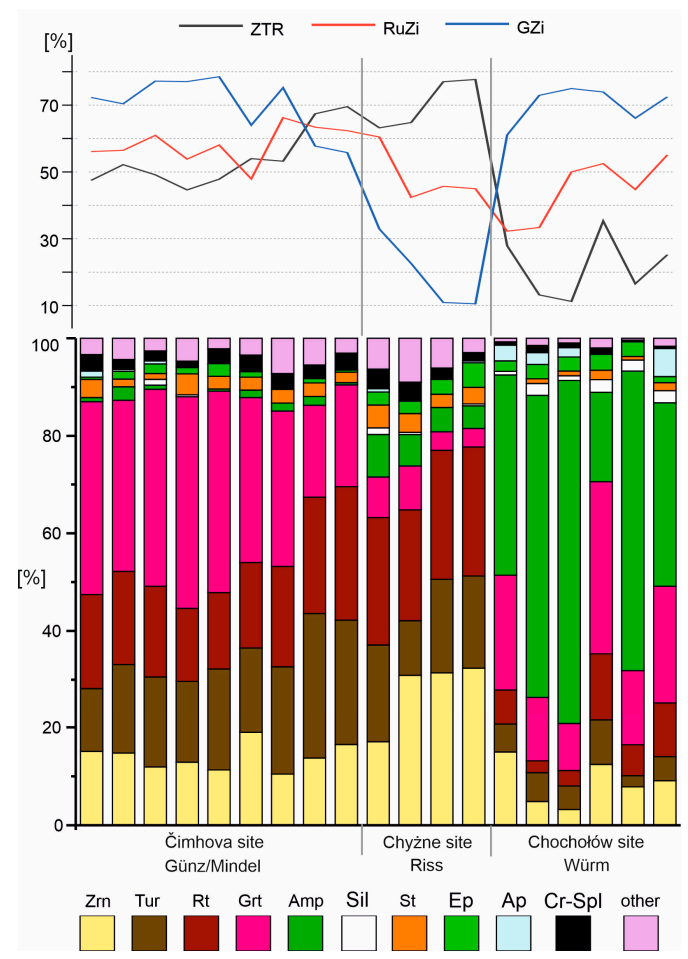

Figure 5. Heavy mineral frequencies and provenance indices for the study deposits in the Orava Basin. Abbreviations: Zrn, zircon; Tur, tourmaline; Rt, rutile; Grt, garnet; Amp, amphibole; Sil, sillimanite; St, staurolite; Ep, epidote; Ap, apatite; Cr-Spl, chromium spinel; Chl, chlorite; Mnz, monazite; Brk, brookite; ZTR, zircon-tourmaline-rutile index; GZi, garnet-zircon index; RuZi, rutile-zircon index; $\mathrm{HM} \mathrm{wt} \%$, weight percent of the heavy fraction. Indices calculated according to Morton and Hallsworth [72]). 
Table 2. Abundances of heavy minerals and provenance indices in the loess-like deposits of the Orava Basin.

\begin{tabular}{|c|c|c|c|c|c|c|c|c|c|c|c|c|c|c|c|c|c|c|c|c|}
\hline Samples & & OP & Zrn & Tur & $\mathbf{R t}$ & Grt & Amp & Sil & St & Ep & Ap & $\mathrm{Cr}-\mathrm{Spl}$ & Chl & Mnz & Brk & ZTR & RuZi & GZi & counts & HM wt $\%$ \\
\hline \multirow{9}{*}{ Günz/Mindel } & Či_1 & 38.3 & 15.1 & 13.0 & 19.3 & 39.5 & 0.8 & 0.0 & 3.8 & 0.4 & 1.3 & 3.4 & 2.5 & 0.0 & 0.8 & 47 & 56 & 72 & 338 & 0.7 \\
\hline & Či 2 & 43.1 & 14.7 & 18.3 & 19.1 & 35.1 & 2.8 & 0.0 & 1.6 & 1.6 & 0.4 & 2.0 & 3.6 & 0.0 & 0.8 & 52 & 56 & 70 & 351 & 0.6 \\
\hline & Či_3 & 44.2 & 11.9 & 18.6 & 18.6 & 40.4 & 0.9 & 1.2 & 1.2 & 2.0 & 0.6 & 2.0 & 2.0 & 0.0 & 0.6 & 49 & 61 & 77 & 344 & 0.7 \\
\hline & Či_ 4 & 38.0 & 12.9 & 16.7 & 15.0 & 43.3 & 0.0 & 0.4 & 4.3 & 1.3 & 0.0 & 1.3 & 4.3 & 0.0 & 0.4 & 45 & 54 & 77 & 333 & 0.8 \\
\hline & Či_5 & 43.9 & 11.3 & 20.9 & 15.7 & 41.3 & 0.4 & 0.0 & 2.6 & 2.6 & 0.0 & 3.0 & 2.2 & 0.0 & 0.0 & 48 & 58 & 79 & 330 & 0.7 \\
\hline & Či_6 & 40.4 & 19.0 & 17.5 & 17.5 & 33.8 & 1.5 & 0.0 & 2.7 & 1.1 & 0.0 & 3.4 & 2.7 & 0.0 & 0.8 & 54 & 48 & 64 & 363 & 0.7 \\
\hline & Či_7 & 52.4 & 10.5 & 22.2 & 20.6 & 31.9 & 1.6 & 0.0 & 2.8 & 0.0 & 0.0 & 3.2 & 7.3 & 0.0 & 0.0 & 53 & 66 & 75 & 348 & 0.7 \\
\hline & Či_8 & 58.7 & 13.8 & 29.8 & 23.9 & 18.8 & 1.8 & 0.0 & 2.8 & 0.9 & 0.0 & 2.8 & 3.7 & 0.0 & 1.8 & 67 & 63 & 58 & 318 & 0.4 \\
\hline & Či_9 & 59.2 & 16.5 & 25.7 & 27.4 & 20.9 & 0.4 & 0.0 & 2.2 & 0.4 & 0.0 & 3.5 & 2.6 & 0.0 & 0.4 & 70 & 62 & 56 & 391 & 0.4 \\
\hline \multirow{4}{*}{ Riss } & Chyż_1 & 51.9 & 17.1 & 20.1 & 26.1 & 8.4 & 8.7 & 1.3 & 4.7 & 2.7 & 0.7 & 4.0 & 1.7 & 1.3 & 3.3 & 63 & 60 & 33 & 314 & 0.9 \\
\hline & Chyż_2 & 67.7 & 30.9 & 11.2 & 22.7 & 9.0 & 6.4 & 0.4 & 3.9 & 2.6 & 0.0 & 3.9 & 2.1 & 1.3 & 5.6 & 65 & 42 & 23 & 333 & 1.0 \\
\hline & Chyż_3 & 49.1 & 31.4 & 19.2 & 26.4 & 3.8 & 5.0 & 0.0 & 2.7 & 3.1 & 0.0 & 2.3 & 0.4 & 1.1 & 4.6 & 77 & 46 & 11 & 361 & 1.1 \\
\hline & Chyż_4 & 58.0 & 32.4 & 18.9 & 26.5 & 3.8 & 4.6 & 0.4 & 3.4 & 5.0 & 0.4 & 1.7 & 0.0 & 0.8 & 2.1 & 78 & 45 & 10 & 338 & 0.8 \\
\hline \multirow{6}{*}{ Würm } & Choch_1 & 139.8 & 15.0 & 5.7 & 7.1 & 23.6 & 41.1 & 0.7 & 0.0 & 2.1 & 3.2 & 0.7 & 0.0 & 0.4 & 0.4 & 28 & 32 & 61 & 350 & 1.3 \\
\hline & Choch_2 & 230.6 & 4.9 & 5.9 & 2.4 & 13.2 & 62.0 & 2.4 & 1.0 & 2.9 & 2.4 & 1.5 & 0.0 & 0.0 & 1.5 & 13 & 33 & 73 & 305 & 1.1 \\
\hline & Choch_3 & 336.8 & 3.2 & 4.8 & 3.2 & 9.6 & 70.5 & 1.0 & 1.0 & 2.9 & 1.9 & 1.0 & 0.0 & 0.3 & 0.6 & 11 & 50 & 75 & 314 & 0.4 \\
\hline & Choch_4 & 440.0 & 12.4 & 9.2 & 13.7 & 35.3 & 18.3 & 2.6 & 2.0 & 3.3 & 0.0 & 1.3 & 0.0 & 0.0 & 2.0 & 35 & 53 & 74 & 353 & 0.2 \\
\hline & Choch_5 & 532.7 & 7.9 & 2.2 & 6.4 & 15.4 & 61.4 & 2.2 & 0.7 & 3.0 & 0.0 & 0.4 & 0.0 & 0.0 & 0.4 & 16 & 45 & 66 & 367 & 0.8 \\
\hline & Choch_€ & 631.1 & 9.1 & 5.0 & 11.2 & 24.0 & 37.6 & 2.5 & 1.7 & 1.2 & 5.8 & 0.4 & 0.0 & 0.0 & 1.7 & 25 & 55 & 73 & 342 & 0.6 \\
\hline
\end{tabular}

Abbreviations: Či, Čimhova site; Chyż, Chyżne site; Choch, Chochołów site; OP, opaque minerals; Zrn, zircon; Tur, tourmaline; Rt, rutile; Grt, garnet; Amp, amphibole; Sil, sillimanite; St, staurolite; Ep, epidote; Ap, apatite; Cr-Spl, chromate-spinel; Chl, chlorite; Mnz, monazite; Brk, brookite; ZTR, zircon-tourmaline-rutile index: GZi, garnet-zircon index; RuZi, rutile-zircon index; $\mathrm{HM} \mathrm{wt} \%$, weight percent of the heavy fraction. Indices calculated according to Morton and Hallsworth [72]. 

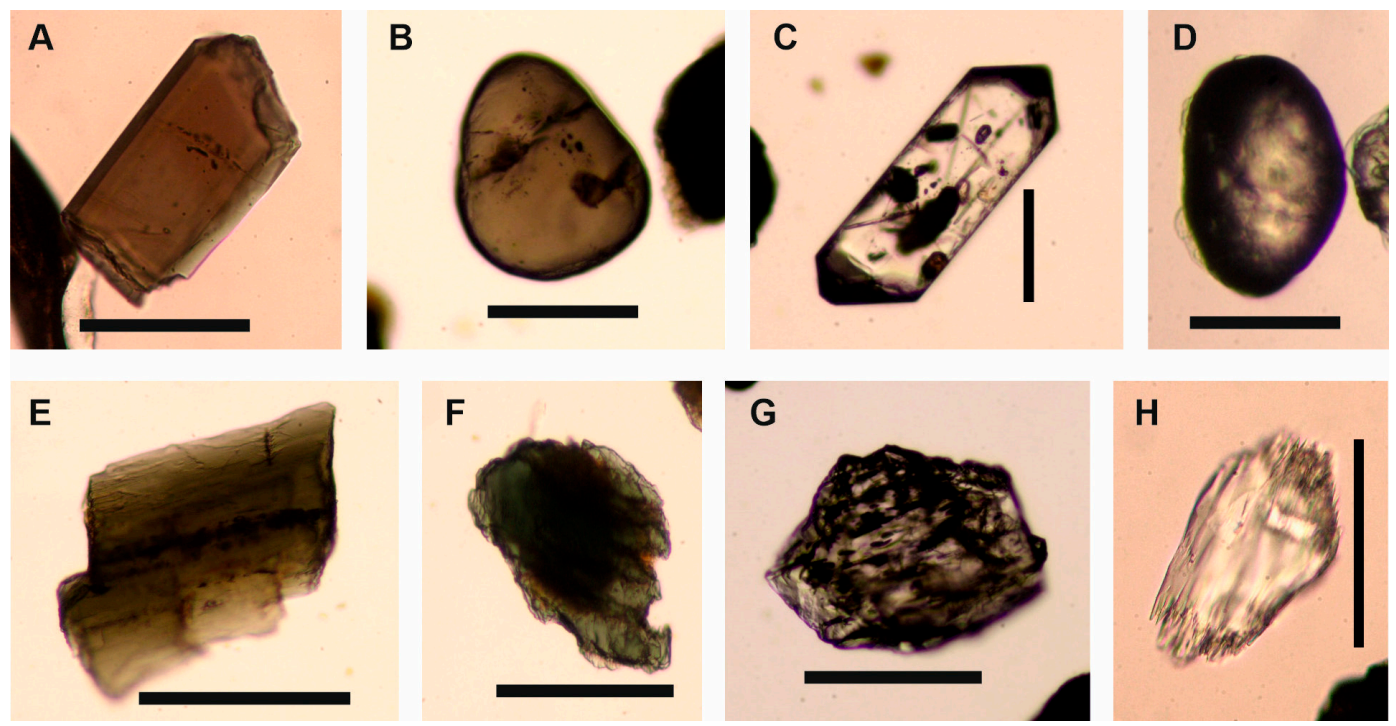

Figure 6. Examples of the morphologies and corrosion of the studied minerals: (A) euhedral tourmaline; (B) rounded tourmaline; (C) euhedral zircon; (D) rounded zircon; (E) uncorroded amphibole; (F) corroded amphibole with dissolution bays; $(\mathbf{G})$ corroded garnet; $(\mathbf{H})$ corroded apatite with hack-saw terminations. Scale bars are $0.1 \mathrm{~mm}$.

Heavy mineral assemblages in sediments of the uppermost (oldest) Günz/Mindel fan in the Čimhova site are generally composed of garnet (up to $43 \%$ ), which is accompanied by ultrastable zircon (10-19\%), tourmaline (13-30\%), and rutile (15-27\%). Other minerals occur in amounts usually not exceeding 3\% each. The ZTR index (zircon + tourmaline + rutile; [73]) is rather moderate and reaches $54 \%$ on average. Very high here is also the GZi index (56-79\%). The contribution of opaque minerals is rather moderate, with the mean value of $46 \%$ (Figure 5 and Table 2).

The middle Riss fan (Chyżne site) is characterized by the dominance of ultrastable minerals. An increase in zircon (up to 31\%) is noticeable when comparing to the older Günz/Mindel fan in the Čimhova site. The ZTR index in these sediments is very high and reaches $78 \%$. Compared to the older Günz/Mindel fan, the garnet content is low and does not exceed 9\%, but amphibole slightly increases up to $9 \%$. Staurolite, sillimanite, and epidote have a low contribution in the Riss fan, however higher than in the older fan. The GZi index is the lowest of the three fans, varying between $10 \%$ and $33 \%$, while the RuZi index varies from 42 to $60 \%$ (mostly around $45 \%$ ). The sediments are characterized by the highest ratio of opaque minerals among the three fans (mean value 57\%) (Figure 5 and Table 2).

Heavy mineral frequencies of the lowermost (youngest) Würm fan (Chochołów site) clearly differ from the two older fans. These are dominated by amphibole (18-70\%), accompanied by garnet (10-35\%), and smaller amounts of sillimanite, epidote, staurolite, and apatite, which usually do not exceed $3 \%$ each. The Chochołów site deposits are characterized by the lowest ZTR index ( $21 \%$ on average), the high and relatively uniform GZi index (61-75\%), and RuZi index from 32 to $55 \%$. The proportion of opaque minerals is the lowest among the three fans (mean value 35\%) (Figure 5 and Table 2).

Three main zircon morphological types were distinguished within the zircon population: rounded, subrounded, and euhedral. Their distribution differs between the sampled deposits. Rounded and subrounded grains prevail in all studied samples. Euhedral zircon in the oldest deposits of the Čimhova site ranges from 29 to $39 \%$, in the middle fan its contents are slightly higher (35-40\%), while in the youngest Chochołów site the content of euhedral zircon is the lowest (16-23\%) (Figure 7). 


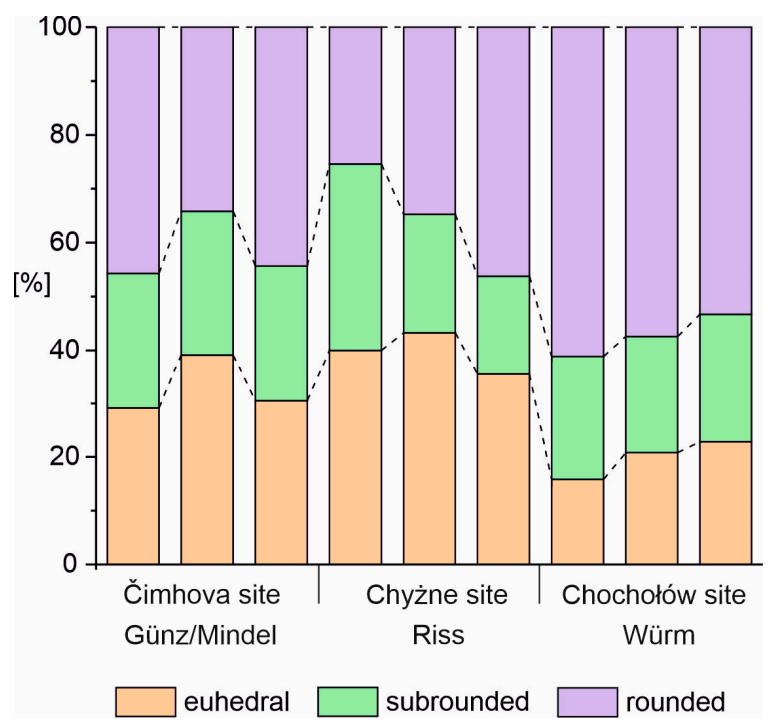

Figure 7. Abundances of morphological types of zircon in the studied deposits from the Orava Basin.

Despite the differing contributions of heavy minerals, the chemical composition of provenance-sensitive minerals is very similar in all studied fans.

The garnet population is dominated by almandine (mostly in the range $50-70 \mathrm{~mol} \%$ ), which is mostly accompanied by grossular and pyrope (up to $29 \mathrm{~mol} \%$ and to $24 \mathrm{~mol} \%$, respectively). Individual garnets display the spessartine content up to $15 \mathrm{~mol} \%$, while andradite and uvarovite are usually low ( $<3 \mathrm{~mol} \%$ ). Spessartine reaches up to $38 \mathrm{~mol} \%$ in one grain. This garnet chemical composition and diversity is typical for all three studied garnet populations (Figure 8 and Table 3).

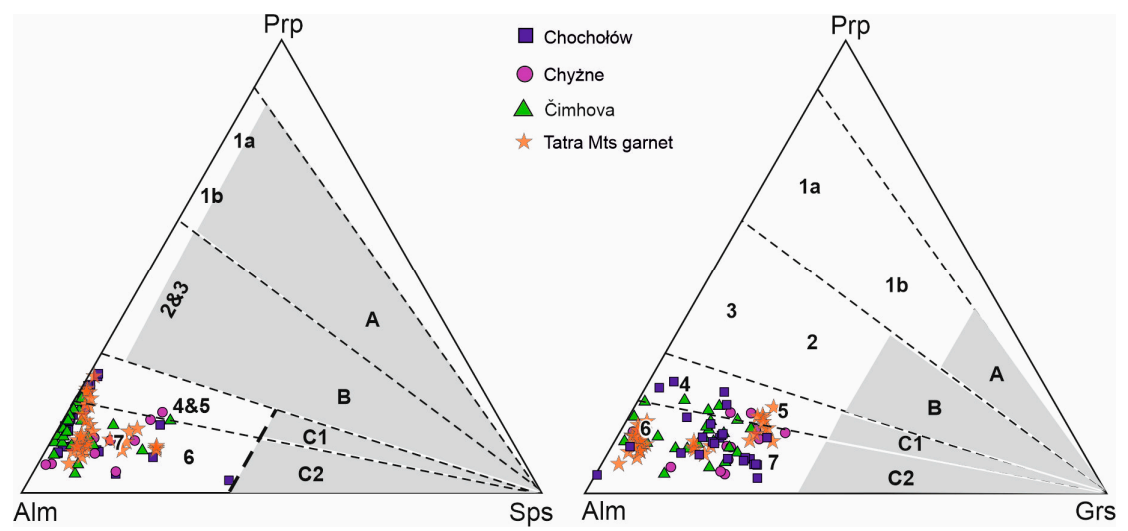

Figure 8. Composition of garnets from the UHP/HP metamorphic conditions in the "pyrope-almandine-grossular" classification diagrams (according to Aubrecht et al. [74] and references therein; Méres et al. [75]): field A—garnet compositions from the UHP/HP conditions; field B—garnet compositions from granulite and eclogite facies conditions; field C1—transitional field of garnet compositions from high amphibolite to granulite facies conditions; field C2-garnet compositions from amphibolite facies conditions (this field includes also garnet from blue schists, skarns, serpentinites, igneous rocks, etc.). 1a—garnet from UHP eclogites, garnet—peridotites and kimberlites; $1 \mathrm{~b}$-garnet from UHP eclogites; 2-garnet from HP eclogites and HP mafic granulites; 3 - garnet from HP felsic and intermediate granulites; 4 -garnet from gneisses metamorphosed under P-T conditions transitional to the granulite and amphibolite facies; 5-garnet from amphibolites metamorphosed under P-T conditions transitional to the granulite and amphibolite facies; 6-garnet from gneisses metamorphosed under amphibolite facies conditions; 7-garnet from amphibolites metamorphosed under amphibolite facies conditions. Location of garnet spots from the Tatra Mountains based on analyses of Gawęda et al. [76] and Janák et al. [77,78]. 
Table 3. Representative analyses of garnet from the studied sites.

\begin{tabular}{cccccccccccccc}
\hline Label & \multicolumn{4}{c}{ Chochołów } & \multicolumn{4}{c}{ Chyżne } & \multicolumn{5}{c}{ Čimhova } \\
\hline$[\mathrm{wt} \%]$ & 1 & 2 & 3 & 4 & 1 & 2 & 3 & 4 & 1 & 2 & 3 & 4 \\
\hline $\mathrm{SiO}_{2}$ & 36.74 & 37.36 & 36.12 & 37.92 & 37.07 & 38.09 & 38.33 & 37.43 & 37.37 & 37.97 & 38.36 & 38.11 \\
$\mathrm{Al}_{2} \mathrm{O}_{3}$ & 21.08 & 20.64 & 20.34 & 21.32 & 21.07 & 21.10 & 21.16 & 21.22 & 20.79 & 21.30 & 21.35 & 21.43 \\
$\mathrm{Cr}_{2} \mathrm{O}_{3}$ & 0.19 & 0.09 & 1.81 & 0.07 & 0.65 & 0.00 & 0.66 & 0.15 & 0.06 & 0.01 & 0.14 & 0.85 \\
$\mathrm{TiO}_{2}$ & 0.03 & 0.15 & 0.04 & 0.06 & 0.16 & 0.07 & 0.21 & 0.14 & 0.03 & 0.06 & 0.07 & 0.08 \\
$\mathrm{MgO}$ & 2.33 & 1.44 & 0.57 & 6.08 & 0.95 & 4.37 & 2.97 & 1.25 & 2.73 & 2.48 & 5.14 & 3.32 \\
$\mathrm{CaO}$ & 1.27 & 10.73 & 0.21 & 2.00 & 8.01 & 8.88 & 10.64 & 8.22 & 0.91 & 8.17 & 3.29 & 6.98 \\
$\mathrm{MnO}$ & 2.51 & 0.67 & 16.17 & 0.58 & 5.26 & 0.46 & 5.26 & 0.46 & 0.91 & 0.58 & 0.31 & 7.41 \\
$\mathrm{FeO}$ tot & 36.23 & 28.46 & 25.98 & 32.05 & 27.06 & 27.56 & 22.02 & 31.61 & 37.91 & 30.54 & 32.13 & 23.74 \\
Total & 100.37 & 99.54 & 101.24 & 100.07 & 100.22 & 100.53 & 101.25 & 100.47 & 100.71 & 101.10 & 100.78 & 101.91 \\
\hline & & & & Garnet End-Members [mol\%] & & & & & \\
\hline Almandine & 81 & 62 & 59 & 69 & 61 & 57 & 47 & 70 & 84 & 66 & 70 & 51 \\
Andradite & 0 & 2 & 0 & 1 & 0 & 3 & 1 & 0 & 1 & 1 & 0 & 0 \\
Grossular & 3 & 29 & 0 & 4 & 21 & 22 & 27 & 23 & 2 & 22 & 8 & 17 \\
Pyrope & 9 & 6 & 2 & 24 & 4 & 17 & 12 & 5 & 11 & 10 & 20 & 13 \\
Spessartine & 6 & 2 & 38 & 1 & 12 & 1 & 12 & 1 & 2 & 1 & 1 & 16 \\
Uvarovite & 1 & 0 & 1 & 0 & 2 & 0 & 2 & 0 & 0 & 0 & 0 & 3 \\
\hline
\end{tabular}

Tourmaline populations are also characterized by an uniform chemical composition. Tourmalines display $\mathrm{X}$-site vacancy (Xvac) values typically lower than 0.5 , which classify them to the alkali primary group. Only a few grains featured by Xvac values above 0.5 belong to the $X$-vacant group [68]. The dominating divalent cations in the Y-site position of the tourmaline structure are Fe and $\mathrm{Mg}$, whose amounts, and accordingly the $\mathrm{Mg} /(\mathrm{Mg}+\mathrm{Fe})$ ratio values, vary in a very broad range from below 0.2 to over 0.8. Consequently, the predominant number of tourmaline represents the schorl-dravite series (Figure 9 and Table 4). The fluoride ion, $\mathrm{Ti}$, and the calculated $\mathrm{Li}$ contents in all tourmalines do not exceed $0.3 \mathrm{apfu}$. The remaining $\mathrm{Mn}, \mathrm{Cr}, \mathrm{V}$, and $\mathrm{Zn}$ contents are very low and mostly do not exceed 0.04 apfu (Table 4).

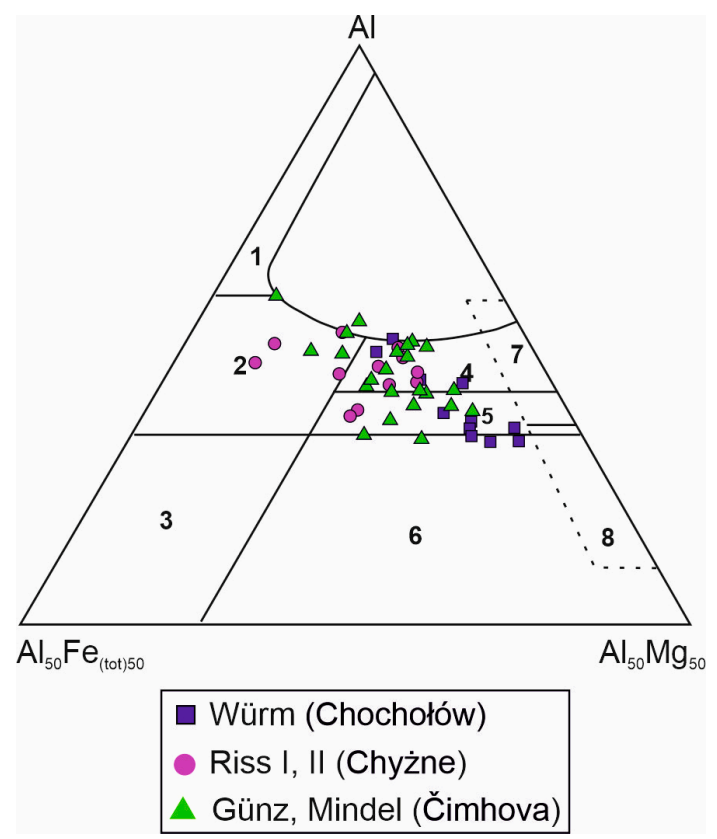

Figure 9. Provenance diagrams for tourmalines from the studied deposits: 1-Li-rich granitoids, pegmatites and aplites; 2-Li-poor granitoids, pegmatites and aplites; 3-hydrothermally altered, granitic rocks; 4-Al-rich metapelites and metapsammites; 5 -Al-poor metapelites and metapsammites; 6- $\mathrm{Fe}^{3+}$-rich quartz-tourmaline rocks, calc silicates and metapelites; 7-Ca-poor ultramafites; 8 -metacarbonates and metapyroxenites [65]. 
Table 4. Representative analyses of tourmaline from the studied sites.

\begin{tabular}{|c|c|c|c|c|c|c|c|c|c|c|c|c|}
\hline \multirow{2}{*}{$\begin{array}{c}\text { Locality } \\
{[w t \%]}\end{array}$} & \multicolumn{4}{|c|}{ Chyżne } & \multicolumn{4}{|c|}{ Chochołów } & \multicolumn{4}{|c|}{ Čimhova } \\
\hline & 1 & 2 & 3 & 4 & 1 & 2 & 3 & 4 & 1 & 2 & 3 & 4 \\
\hline $\mathrm{SiO}_{2}$ & 34.70 & 36.18 & 35.31 & 35.94 & 37.26 & 36.86 & 35.56 & 36.65 & 35.85 & 35.92 & 36.69 & 35.79 \\
\hline $\mathrm{TiO}_{2}$ & 0.19 & 0.53 & 1.12 & 0.87 & 0.33 & 1.71 & 0.72 & 1.42 & 0.64 & 0.78 & 0.28 & 0.77 \\
\hline $\mathrm{Al}_{2} \mathrm{O}_{3}$ & 32.48 & 30.92 & 33.29 & 33.97 & 30.65 & 29.65 & 34.75 & 29.99 & 29.49 & 34.13 & 33.51 & 34.54 \\
\hline $\mathrm{V}_{2} \mathrm{O}_{3}$ & 0.03 & 0.00 & 0.06 & 0.18 & 0.00 & 0.09 & 0.05 & 0.08 & 0.07 & 0.04 & 0.13 & 0.09 \\
\hline $\mathrm{Cr}_{2} \mathrm{O}_{3}$ & 0.09 & 0.06 & 0.00 & 0.00 & 0.00 & 0.07 & 0.00 & 0.00 & 0.00 & 0.13 & 0.12 & 0.00 \\
\hline $\mathrm{FeO}$ & 13.43 & 9.97 & 7.92 & 6.54 & 5.04 & 3.27 & 6.66 & 3.08 & 10.43 & 6.91 & 10.87 & 8.75 \\
\hline $\mathrm{MgO}$ & 2.17 & 5.68 & 5.68 & 6.27 & 8.88 & 10.39 & 5.65 & 10.01 & 6.11 & 5.98 & 3.53 & 4.26 \\
\hline $\mathrm{CaO}$ & 0.08 & 0.16 & 0.96 & 0.89 & 0.09 & 2.30 & 1.13 & 2.41 & 0.38 & 0.84 & 0.02 & 0.33 \\
\hline $\mathrm{MnO}$ & 0.29 & 0.03 & 0.03 & 0.00 & 0.00 & 0.02 & 0.00 & 0.00 & 0.03 & 0.05 & 0.03 & 0.08 \\
\hline $\mathrm{ZnO}$ & 0.13 & 0.10 & 0.00 & 0.00 & 0.00 & 0.04 & 0.00 & 0.00 & 0.01 & 0.20 & 0.00 & 0.16 \\
\hline $\mathrm{Na}_{2} \mathrm{O}$ & 2.35 & 2.66 & 1.70 & 1.76 & 2.94 & 1.63 & 1.58 & 1.53 & 2.46 & 2.06 & 1.44 & 1.92 \\
\hline $\mathrm{K}_{2} \mathrm{O}$ & 0.05 & 0.00 & 0.02 & 0.00 & 0.00 & 0.03 & 0.05 & 0.01 & 0.01 & 0.04 & 0.00 & 0.02 \\
\hline $\mathrm{F}$ & 0.03 & 0.31 & 0.21 & 0.35 & 0.05 & 0.09 & 0.11 & 0.23 & 0.11 & 0.22 & 0.31 & 0.29 \\
\hline $\mathrm{H}_{2} \mathrm{O}^{*}$ & 3.53 & 3.47 & 3.56 & 3.54 & 3.65 & 3.68 & 3.65 & 3.59 & 3.52 & 3.62 & 3.51 & 3.55 \\
\hline $\mathrm{B}_{2} \mathrm{O}_{3}$ * & 10.27 & 10.49 & 10.61 & 10.75 & 10.66 & 10.78 & 10.73 & 10.71 & 10.34 & 10.78 & 10.60 & 10.68 \\
\hline $\mathrm{Li}_{2} \mathrm{O}^{*}$ & 0.15 & 0.13 & 0.25 & 0.29 & 0.34 & 0.40 & 0.37 & 0.46 & 0.10 & 0.33 & 0.15 & 0.30 \\
\hline $\mathrm{O}=\mathrm{F}$ & 0.01 & 0.13 & 0.09 & 0.15 & 0.02 & 0.04 & 0.05 & 0.09 & 0.04 & 0.09 & 0.13 & 0.12 \\
\hline Total & 99.95 & 100.55 & 100.64 & 101.20 & 99.87 & 100.96 & 100.96 & 100.06 & 99.46 & 101.94 & 101.05 & 101.39 \\
\hline \multicolumn{13}{|c|}{ structural formula based on 31 anions (O. OH. F) } \\
\hline B & 3.000 & 3.000 & 3.000 & 3.000 & 3.000 & 3.000 & 3.000 & 3.000 & 3.000 & 3.000 & 3.000 & 3.000 \\
\hline $\mathrm{T}: \mathrm{Si}$ & 5.874 & 5.998 & 5.785 & 5.811 & 6.074 & 5.940 & 5.761 & 5.945 & 6.028 & 5.788 & 6.016 & 5.823 \\
\hline $\mathrm{Al}$ & 0.126 & 0.002 & 0.215 & 0.189 & 0.000 & 0.060 & 0.239 & 0.055 & 0.000 & 0.212 & 0.000 & 0.177 \\
\hline $\mathrm{Z}: \mathrm{Al}$ & 6.000 & 6.000 & 6.000 & 6.000 & 5.889 & 5.572 & 6.000 & 5.679 & 5.844 & 6.000 & 6.000 & 6.000 \\
\hline $\mathrm{Mg}$ & 0.000 & 0.000 & 0.000 & 0.000 & 0.111 & 0.428 & 0.000 & 0.321 & 0.156 & 0.000 & 0.000 & 0.000 \\
\hline Y: Al & 0.354 & 0.039 & 0.214 & 0.285 & 0.000 & 0.000 & 0.397 & 0.000 & 0.000 & 0.271 & 0.475 & 0.447 \\
\hline $\mathrm{Ti}$ & 0.024 & 0.066 & 0.138 & 0.106 & 0.040 & 0.207 & 0.088 & 0.173 & 0.081 & 0.095 & 0.034 & 0.095 \\
\hline V & 0.004 & 0.000 & 0.007 & 0.024 & 0.000 & 0.011 & 0.006 & 0.010 & 0.009 & 0.006 & 0.017 & 0.011 \\
\hline $\mathrm{Cr}$ & 0.012 & 0.008 & 0.000 & 0.000 & 0.000 & 0.009 & 0.000 & 0.000 & 0.000 & 0.016 & 0.015 & 0.000 \\
\hline $\mathrm{Fe}^{3+}$ & 0.000 & 0.000 & 0.000 & 0.000 & 0.000 & 0.000 & 0.000 & 0.000 & 0.000 & 0.000 & 0.000 & 0.000 \\
\hline $\mathrm{Mg}$ & 0.548 & 1.404 & 1.386 & 1.510 & 2.048 & 2.067 & 1.365 & 2.099 & 1.376 & 1.436 & 0.863 & 1.033 \\
\hline $\mathrm{Mn}$ & 0.042 & 0.004 & 0.004 & 0.000 & 0.000 & 0.003 & 0.000 & 0.000 & 0.004 & 0.007 & 0.005 & 0.010 \\
\hline $\mathrm{Fe}^{2+}$ & 1.902 & 1.382 & 1.085 & 0.884 & 0.687 & 0.440 & 0.902 & 0.418 & 1.466 & 0.931 & 1.491 & 1.191 \\
\hline $\mathrm{Zn}$ & 0.017 & 0.012 & 0.000 & 0.000 & 0.000 & 0.005 & 0.000 & 0.000 & 0.001 & 0.023 & 0.000 & 0.019 \\
\hline $\mathrm{Li}^{*}$ & 0.100 & 0.087 & 0.166 & 0.190 & 0.225 & 0.257 & 0.242 & 0.300 & 0.064 & 0.215 & 0.100 & 0.194 \\
\hline $\mathrm{X}: \mathrm{Ca}$ & 0.015 & 0.028 & 0.168 & 0.154 & 0.015 & 0.398 & 0.197 & 0.420 & 0.068 & 0.146 & 0.003 & 0.057 \\
\hline $\mathrm{Na}$ & 0.770 & 0.855 & 0.541 & 0.551 & 0.929 & 0.509 & 0.497 & 0.481 & 0.801 & 0.644 & 0.456 & 0.606 \\
\hline $\mathrm{K}$ & 0.011 & 0.000 & 0.005 & 0.000 & 0.000 & 0.006 & 0.010 & 0.001 & 0.002 & 0.009 & 0.000 & 0.004 \\
\hline cat sum & 18.796 & 18.883 & 18.714 & 18.705 & 19.018 & 18.913 & 18.704 & 18.902 & 18.898 & 18.798 & 18.475 & 18.667 \\
\hline$X_{\text {vac }}$ & 0.204 & 0.117 & 0.286 & 0.295 & 0.056 & 0.087 & 0.296 & 0.098 & 0.130 & 0.202 & 0.541 & 0.333 \\
\hline $\mathrm{OH}$ & 3.986 & 3.839 & 3.889 & 3.821 & 3.972 & 3.957 & 3.944 & 3.885 & 3.944 & 3.890 & 3.837 & 3.849 \\
\hline $\mathrm{F}$ & 0.014 & 0.161 & 0.111 & 0.179 & 0.028 & 0.043 & 0.056 & 0.115 & 0.056 & 0.110 & 0.163 & 0.151 \\
\hline Name & Schorl & Dravite & Dravite & Dravite & Dravite & Dravite & Dravite & Dravite & Schorl & Dravite & Foitite & Schorl \\
\hline
\end{tabular}

The analyzed amphiboles belong to the $(\mathrm{OH}, \mathrm{F}$ and $\mathrm{Cl})$-group and the calcium subgroup. They are represented by magnesio- or ferro-hornblende (Figure 10 and Table 5). Only two amphiboles from the Chyżne site represent cummingtonite from the Mg-Fe-Mn subgroup (Table 5). 


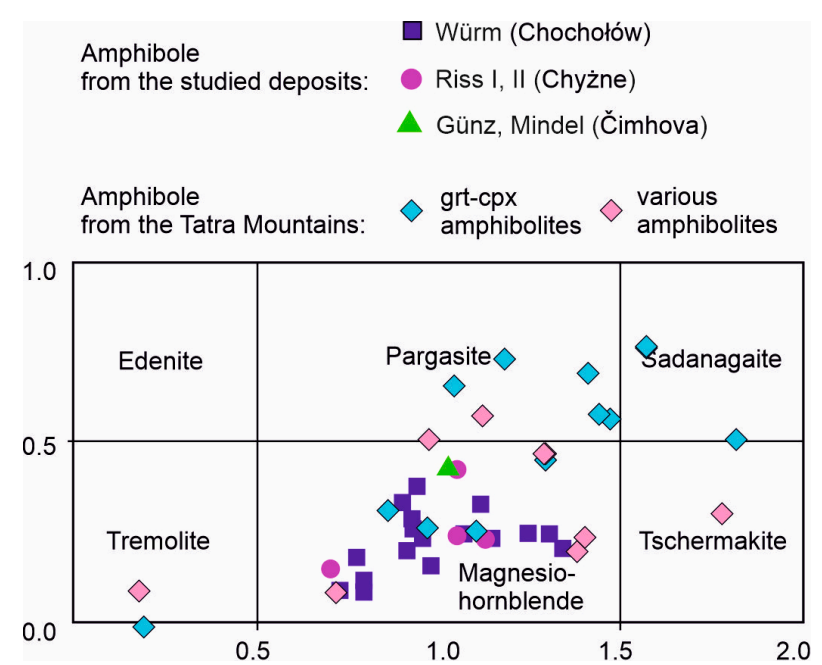

Figure 10. Composition and classification of the amphibole grains studied [69]. Data on minerals from rocks of the Tatra Mountains come from Gawęda et al. [76] and Janák et al. [77,78]).

Table 5. Representative amphibole composition from the Chochołów and Chyżne sites and amphibole composition from the Čimhova site.

\begin{tabular}{|c|c|c|c|c|c|c|c|c|c|c|c|}
\hline \multirow{2}{*}{$\begin{array}{c}\text { Studied Locality } \\
{[\mathrm{wt} \%]}\end{array}$} & \multicolumn{5}{|c|}{ Chochołów } & \multicolumn{5}{|c|}{ Chyżne } & \multirow{2}{*}{$\frac{\text { Čimhova }}{1}$} \\
\hline & 1 & 2 & 3 & 4 & 5 & 1 & 2 & 3 & 4 & 5 & \\
\hline $\mathrm{SiO}_{2}$ & 45.04 & 47.94 & 44.01 & 47.56 & 50.16 & 51.94 & 46.51 & 52.30 & 46.31 & 54.84 & 44.24 \\
\hline $\mathrm{TiO}_{2}$ & 0.99 & 0.86 & 1.07 & 1.03 & 0.69 & 0.41 & 0.93 & 0.15 & 1.03 & 0.04 & 0.64 \\
\hline $\mathrm{Al}_{2} \mathrm{O}_{3}$ & 11.85 & 8.67 & 11.32 & 8.88 & 7.35 & 5.66 & 10.87 & 0.72 & 10.00 & 0.80 & 12.08 \\
\hline $\mathrm{Cr}_{2} \mathrm{O}_{3}$ & 0.06 & 0.08 & 0.12 & 0.08 & 0.03 & 0.38 & 0.02 & 0.00 & 0.07 & 0.01 & 0.02 \\
\hline $\mathrm{MnO}$ & 0.25 & 0.28 & 0.27 & 0.28 & 0.24 & 0.25 & 0.28 & 0.77 & 0.30 & 0.57 & 0.44 \\
\hline $\mathrm{FeO}$ & 12.05 & 12.61 & 16.72 & 13.02 & 10.56 & 5.23 & 11.31 & 17.53 & 13.61 & 22.84 & 13.17 \\
\hline $\mathrm{Fe}_{2} \mathrm{O}_{3} *$ & 3.75 & 2.45 & 1.88 & 1.33 & 1.57 & 3.13 & 2.72 & 8.47 & 2.34 & 0.00 & 2.13 \\
\hline $\mathrm{ZnO}$ & 0.00 & 0.00 & 0.07 & 0.06 & 0.06 & 0.00 & 0.17 & 0.00 & 0.01 & 0.04 & 0.00 \\
\hline $\mathrm{MgO}$ & 10.88 & 11.99 & 8.54 & 11.88 & 14.14 & 17.98 & 12.04 & 19.35 & 10.93 & 17.53 & 10.66 \\
\hline $\mathrm{CaO}$ & 10.68 & 11.33 & 11.55 & 11.79 & 11.76 & 11.44 & 11.35 & 1.16 & 11.35 & 0.86 & 11.89 \\
\hline $\mathrm{Na}_{2} \mathrm{O}$ & 1.11 & 0.86 & 0.99 & 0.79 & 0.65 & 1.12 & 1.14 & 0.01 & 0.98 & 0.04 & 1.24 \\
\hline $\mathrm{K}_{2} \mathrm{O}$ & 0.33 & 0.30 & 0.57 & 0.40 & 0.30 & 0.09 & 0.25 & 0.00 & 0.45 & 0.00 & 0.62 \\
\hline $\mathrm{H}_{2} \mathrm{O}^{+}$ & 2.05 & 2.06 & 2.01 & 2.06 & 2.09 & 2.13 & 2.07 & 2.05 & 2.04 & 2.07 & 2.03 \\
\hline Total & 99.05 & 99.44 & 99.11 & 99.14 & 99.58 & 99.75 & 99.65 & 102.51 & 99.41 & 99.64 & 99.16 \\
\hline Group & \multicolumn{11}{|c|}{$\mathrm{OH}, \mathrm{F}, \mathrm{Cl}$} \\
\hline Subgroup & $\mathrm{Ca}$ & $\mathrm{Ca}$ & $\mathrm{Ca}$ & $\mathrm{Ca}$ & $\mathrm{Ca}$ & $\mathrm{Ca}$ & $\mathrm{Ca}$ & \multicolumn{2}{|c|}{$\mathrm{Mg}-\mathrm{Fe}-\mathrm{Mn} \mathrm{Ca}$} & $\mathrm{Mg}-\mathrm{Fe}-\mathrm{Mn}$ & $\mathrm{Ca}$ \\
\hline Species & $\mathrm{Mg}-\mathrm{Hbl}$ & $\mathrm{Mg}-\mathrm{Hbl}$ & $\mathrm{Fe}-\mathrm{Hbl}$ & $\mathrm{Mg}-\mathrm{Hbl}$ & $\mathrm{Mg}-\mathrm{Hbl}$ & $\mathrm{Mg}-\mathrm{Fe}-\mathrm{Hbl}$ & $\mathrm{Mg}-\mathrm{Hbl}$ & Cum & $\mathrm{Mg}-\mathrm{Hbl}$ & Cum & $\mathrm{Mg}-\mathrm{Hbl}$ \\
\hline
\end{tabular}

\section{Discussion}

\section{Provenance Interpretation}

The composition of the heavy mineral assemblages generally suggests a metamorphic origin, which is indicated by the large amounts of garnet, hornblende, epidote, and also staurolite and sillimanite. There is a clear change in the heavy mineral assemblages between the studied loess-like covers. The oldest one (Čimhova site) is composed of ultrastable minerals and garnet accompanied by small contents of amphibole.

The content of amphibole and epidote increases in the middle fan and dominates among the heavy minerals in the youngest cover of loess-like deposits. Such pattern of heavy mineral distribution may be the result of several processes. First, it must be noted that the Čimhova site is characterized by the largest contribution of the silt and clay fraction among the three studied sites. Such grain-size distribution may favor concentration of dense and small-sized heavy mineral types such as zircon and rutile (see e.g., [1,79]). Besides, factors other than grain-size could have influenced the heavy 
mineral composition. These may include gradual erosion of the source area, or chemical corrosion and dissolution of unstable minerals in older sediments. Deposits building the oldest cover were exposed to weathering processes for a longer period than the younger ones. Therefore, the removal of less resistant minerals, such as amphibole, cannot be excluded. Thus, the final heavy mineral frequencies in the sampled deposits may be the result of several factors: sorting, chemical dissolution, and source lithology.

The lithology and location of the source area may be tracked by analyzing the heavy mineral assemblage and the chemical composition of provenance-sensitive minerals. The presence of garnet, tourmaline, and amphibole indicates an origin mainly from metamorphic rocks of metapelitic and metapsammitic type (Figures 8-10). Calculated probabilities exceed 0.99 for a metamorphic origin of the analyzed garnets. Among metamorphic garnet, the highest probabilities indicate provenance from the amphibolite-facies group (probabilities exceeding 0.70), which refers to mica and garnet-mica schists and amphibolites. There are also a few grains, mostly from the Čimhova site, whose composition suggests an origin from metamorphics of eclogite- (referring to eclogite xenolites, mafic and UHP eclogites) or granulite-facies groups (developed based on metasedimentary, UHT, felsic and other granulites) (Figure 11). The classification scheme in Figure 8 also suggests a similar provenance. Tourmaline derives generally from Al-rich and Al-poor metasediments. Only a few grains display provenance from Li-poor granitic rocks (Figure 9).

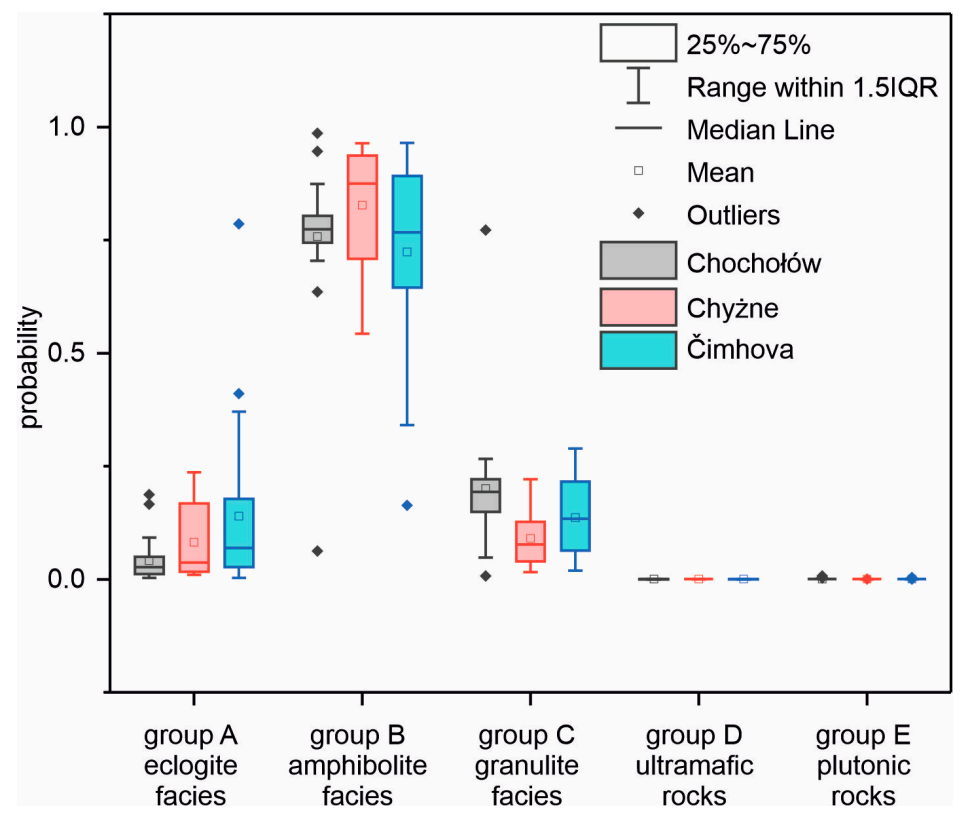

Figure 11. Box plot showing the distribution of the calculated probabilities for the studied garnet provenance regarding source rock and facies groups. Probabilities calculated according to Tolosana-Delgado et al. [71].

Because of the location of the loess-like deposits between large geotectonic units, i.e., the Tatra Mountains to the south and the Outer Flysch Carpathians to the north, the unambiguous identification of the source areas of clastic material is a very difficult task. It has been hypothesized that the material derives, to a large extent, from the flysch sandstones [21]. However, the flysch sandstones building the southern part of the Magura Nappe contain a low number of heavy mineral species comprising ultrastable zircon, tourmaline, rutile, and various amounts of garnet with ZTR index mostly exceeding 80\% (e.g., [80] and references therein). The zircon population in the Magura Nappe is largely (around $80 \%$ ) represented by rounded grains. Amphibole, epidote, and other metamorphic minerals do not occur there. In addition, metamorphic lithologies which could be a potential source for such minerals in the Orava Basin are not exposed within the Magura Nappe. Therefore, flysch sandstones could 
be considered as a source only for the grains of ultrastable minerals. The only known source of metamorphic and igneous rocks is located in the Tatra domain. The Tatra Mountains form a horst structure which was exhumed in the Oligocene-Miocene [81-83]. Therefore, these mountains were already exposed during the sedimentation of the studied loess-like deposits. Considering the Czarny Dunajec River flow direction, it is most probable that the material derives from the western part of the Tatra Mountains.

The pre-Alpine crystalline basement of the Tatricum is mostly dominated by Variscan granitic rocks and a patchwork of metamorphic rocks, overlain by Mesozoic deposits (Figure 12A) (e.g., [84]). The metamorphic basement is subdivided into two tectonic units. The lower unit is composed of medium-grade metasediments such as mica-schists and metaquartzites. The upper unit is built of migmatites, high-grade ortho- and paragneisses, amphibolites with garnet and eclogite relics $[77,78,85,86]$ (Figure 12B).

A
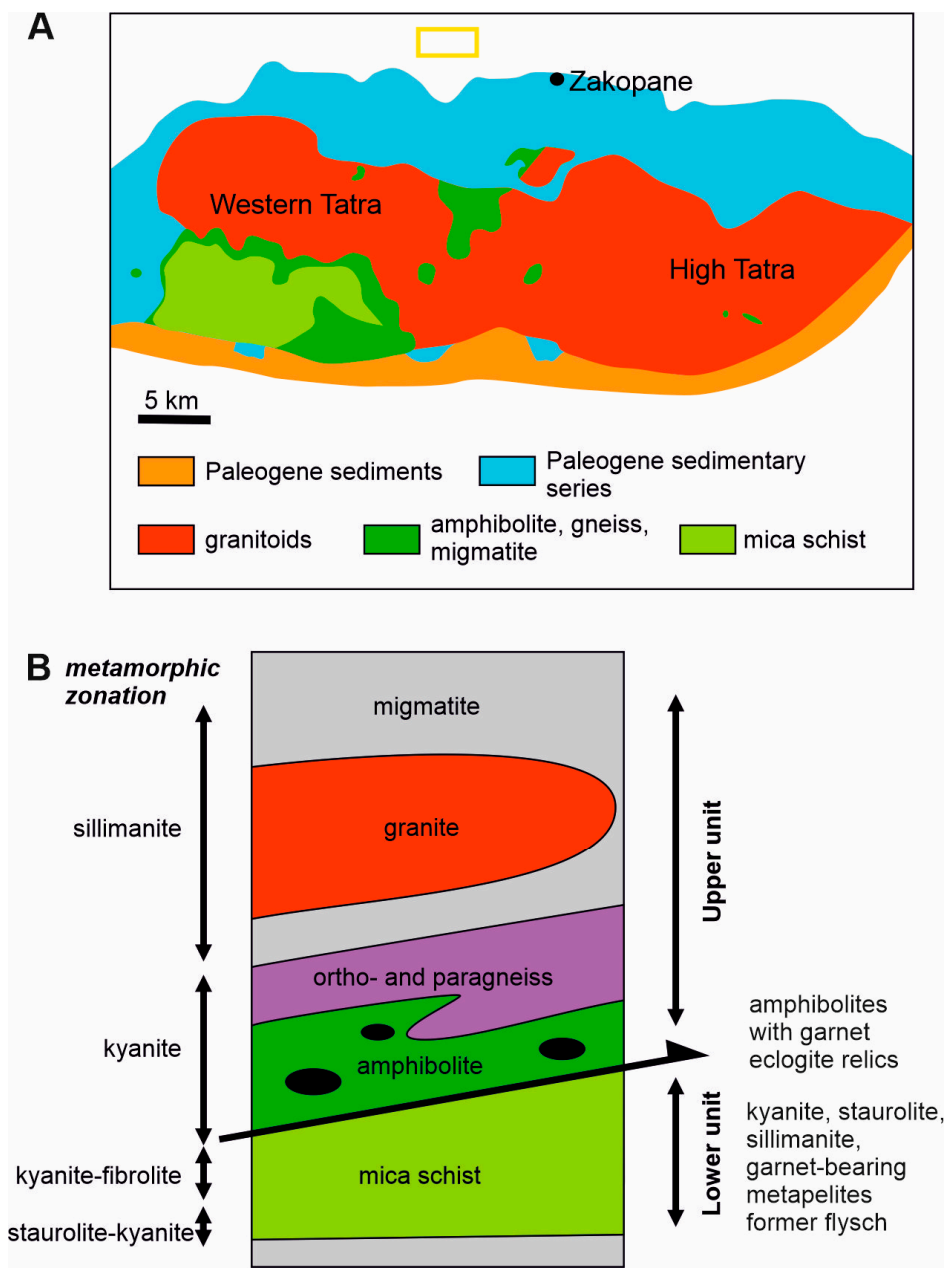

Figure 12. (A) schematic geological map of the Tatra Mountains; (B) simplified succession along the main tectonic units of the Tatra Mountains with respect to lithology and metamorphic zonation (from Janák et al. [78]). The yellow rectangle indicates the sampling area.

The chemical composition of garnet and amphibole from the studied sediments matches the composition of these minerals from the Tatra Mountains (Figures 8 and 10). The gradual change in heavy mineral frequencies between the oldest and youngest loess-like covers may reflect erosion and exposure of deeper parts of the source area. The scheme basically reflects the generalized succession along the main tectonic units of the Tatra Mountains (Figure 12B). Accordingly, heavy mineral assemblages rich in garnet in the oldest deposits (Čimhova site) may derive from the upper part of the succession, 
whereas exposure of the deeper parts of the source area would deliver larger contents of amphibole first to the Chyżne site deposits and then even a larger content to the Chochołów site deposits (Figure 5). Rounded and subrounded zircon grains may derive from the metapelitic and metapsammitic rocks, where they were present as inherited grains, whereas euhedral zircon derives directly from igneous rocks. Stubby zircon prisms with a 2:1 length:width ratio suggest that the euhedral zircon parent rocks were of plutonic origin [87]. The GZi index is the lowest and the euhedral zircon content is the highest in the middle fan (Figure 5 and Table 2), which suggests that erosion reached the granitic body (Figure 12) during sedimentation of the Chyżne site deposits.

Heavy mineral analysis indicated that material was derived from the Western Tatra Mountains. The primary source of the detritus could be older, pre-Quaternary regolith located in the Western Tatra Mountains. This material was introduced into the glacial and glaciofluvial transport and finally deposited by the Czarny Dunajec River in the Orava Basin (Figure 13). Loess-like deposits in the Orava Basin could be additionally formed under long-term aeolian processes. Sand and silt-sized grains were blown out from their exposed, barren palaeochannels beds during the whole Pleistocene [33]. Different modes of transport may be suggested by the polymodal character of grain-size distribution of the studied sediments [33] (Table 1). According to Smalley et al. [88] and Vandenberghe [89] the source of loess could be locally redeposited alluvial material, primary derived from eroded glacial sediments.

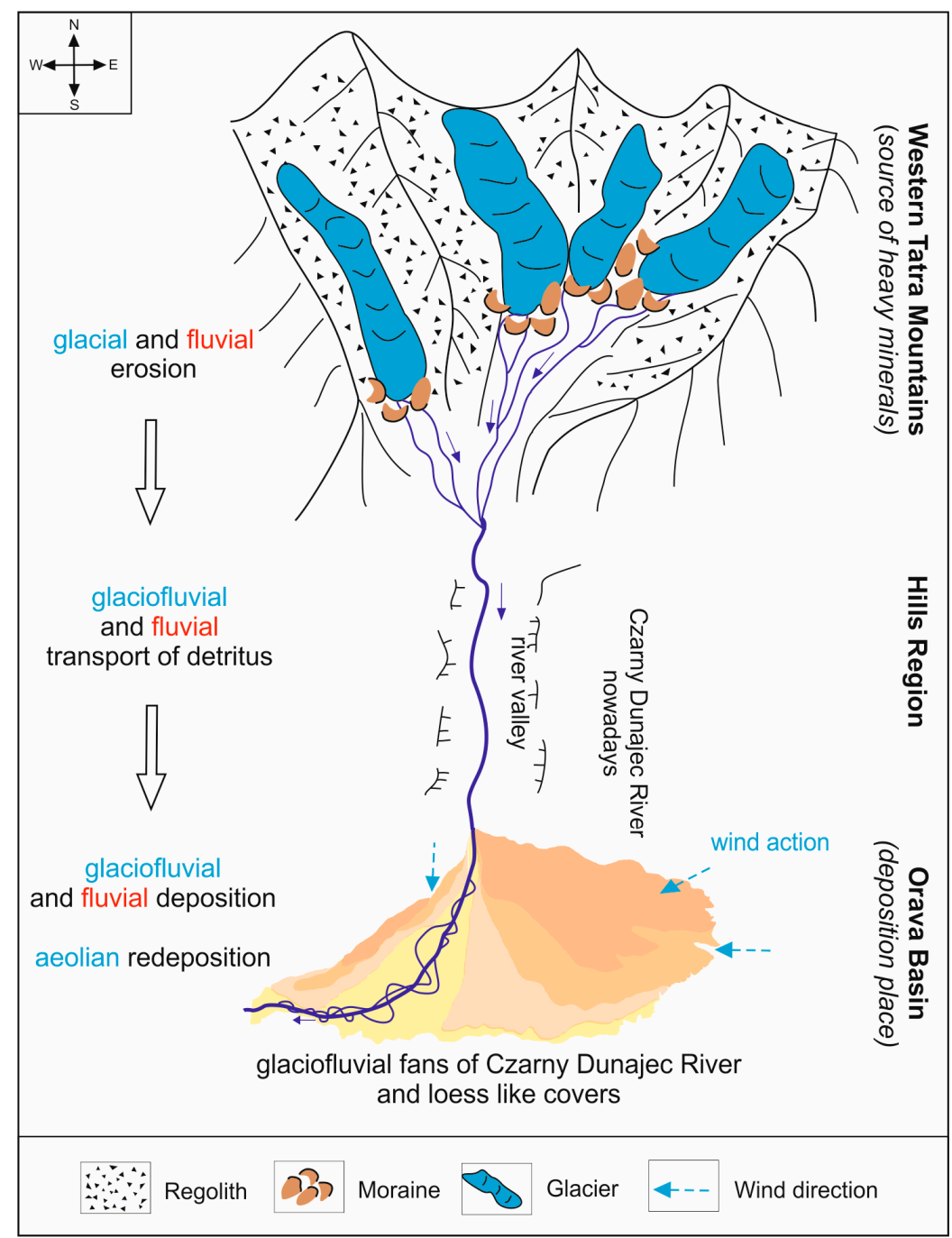

Figure 13. Conceptual model of the provenance of the sand and silt-size deposits in the Orava Basin based on heavy mineral [current study] and textural [33] analysis. Wind directions after Kłapyta et al. [90]. Red font color refers to warm periods, blue font color reflects cold periods 
This study shows an additional advantage of the heavy mineral analyses in the study area. As it was mentioned, many methods fail to help establishing the stratigraphic position of the loess-like deposits. The study shows that the three loess-like covers are represented by different assemblages of heavy minerals. Therefore, the heavy minerals may be used as an additional tool in correlation of these sediments in the Orava Basin.

\section{Conclusions}

The studied loess-like deposits from the Orava Basin differ with regard to changes in heavy mineral composition of the fans of the Czarny Dunajec River. These changes are reflected in the contents of amphibole and epidote, which are more frequent in the younger terraces. This research succeeded to determine the source of the loess-like deposits in the Orava Basin. Garnet and tourmaline composition indicates their provenance from metamorphic lithologies. Additionally, garnet composition suggests rocks of the amphibolite facies as their main sources. Some garnets may also derive from rocks of the granulite and eclogite facies. Garnet and amphibole composition is in accordance with such minerals occurring in the metamorphic rocks of the Western Tatra Mountains. Therefore, it may be concluded that the metamorphic minerals in the studied terraces originated mostly from rocks of the amphibolite facies and subordinately from high-grade eclogite or granulite facies, while euhedral zircon derived from granitic rocks located in the Western Tatra Mountains. Flysch sandstones may be considered as a source only for ultrastable minerals such as rounded zircon, tourmaline, and rutile.

Noteworthy is the fact that, despite the long accumulation period of the loess-like sediments, the direction of material supply to the Orava Basin remained unchanged and thus the source of the material stayed homogeneous. The composition of heavy minerals confirms earlier studies that the source of the loess-like covers were local deposits accumulated earlier in the Orava Basin. The sandy material from which heavy minerals originated was probably transported to the basin as a result of fluvial and fluvioglacial processes from the catchment area of the Czarny Dunajec River (Western Tatra Mountains), while silt as a result of aeolian processes operating in the intramontane basin during periods of violent winter sand storms.

The research shows an additional advantage of the heavy mineral analyses in the study area. As it was mentioned, many methods fail to help establishing the stratigraphic position of the loess-like deposits. The study shows that the three loess-like covers are represented by different assemblages of heavy minerals. Therefore, the heavy minerals may be used as an additional tool in correlation of these sediments in the Orava Basin.

Supplementary Materials: The following are available online at http://www.mdpi.com/2075-163X/10/5/445/s1, Table S1: Supplementary table documenting crude data of mineral counts.

Author Contributions: Conceptualization, D.C. and D.S.; methodology, D.C. and D.S.; validation, D.C. and D.S.; formal analysis, D.C. and D.S.; investigation, D.C. and D.S.; data curation, D.C. and D.S.; writing-original draft preparation, D.C. and D.S.; writing-review and editing, D.C. and D.S. All authors have read and agreed to the published version of the manuscript.

Funding: This research received no external funding.

Acknowledgments: We are grateful to the two reviewers for their comments and suggestions, which helped to improve the quality of the manuscript.

Conflicts of Interest: The authors declare no conflict of interest. The funders had no role in the design of the study, in the collection, analyses, or interpretation of data, in the writing of the manuscript, or in the decision to publish the results.

\section{References}

1. Morton, A.C.; Hallsworth, C.R. Processes controlling the composition of detrital heavy mineral assemblages in sandstones. Sediment. Geol. 1999, 124, 3-29. [CrossRef] 
2. Muhs, D.R.; Cattle, S.R.; Crouvi, O.; Rousseau, D.D.; Sun, J.M.; Zárate, M.A. Loess records. In Mineral Dust: A Key Player in the Earth System; Knippertz, P., Stuut, J.W., Eds.; Springer: Berlin/Heidelberg, Germany, 2014; pp. 411-441.

3. Peng, W.; Wang, Z.; Song, Y.; Pfaff, K.; Luo, Z.; Nie, J.; Chen, W. A comparison of heavy mineral assemblage between the loess and the Red Clay sequences on the Chinese Loess Plateau. Aeolian Res. 2016, 21, 87-91. [CrossRef]

4. Li, Y.; Shi, W.; Aydin, A.; Beroya-Eitner, M.A.; Gao, G. Loess genesis and worldwide distribution. Earth-Sci. Rev. 2020, 201, 102947. [CrossRef]

5. Kukla, G.; An, Z.S. Loess stratigraphy in central China. Palaeogeogr. Palaeoclimatol. Palaeoecol. 1989, 72, 203-225. [CrossRef]

6. Heller, F.; Evans, M.E. Loess magnetism. Rev. Geophys. 1998, 33, 211-240. [CrossRef]

7. Vandenberghe, J.; Huijzer, B.; Mucher, H.; Laan, W. Short climatic oscillations in a western European loess sequence (Kesselt, Belgium). J. Quat. Sci. 1998, 13, 471-485. [CrossRef]

8. Lu, H.Y.; Zhang, F.Q.; Liu, X.D.; Duce, A.R. Periodicities of palaeoclimatic variations recorded by loess-paleosol sequences in China. Quat. Sci. Rev. 2004, 23, 1891-1900. [CrossRef]

9. Nugteren, G.; Vandenberghe, J.; van Huissteden, J.K.; Zhisheng, A. A quaternary climate record based on grain size analysis from the Luochuan loess section on the Central Loess Plateau, China. Glob. Planet. Chang. 2004, 41, 167-183. [CrossRef]

10. Antoine, P.; Rousseau, D.D.; Moine, O.; Kunesch, S.; Hatté, C.; Lang, A.; Tissoux, H.; Zöller, L. Rapid and cyclic aeolian deposition during the Last Glacial in European loess: A high-resolution record from Nussloch. Germany. Quat. Sci. Rev. 2009, 30, 2955-2973. [CrossRef]

11. Li, C.X.; Song, Y.G. The paleoenvironmental significance of magnetic susceptibility in the eolian deposits sequence at the chaona section on the Loess Plateau. J. East China Inst. Technol. 2011, 34, 33-40.

12. Krawczyk, M.; Ryzner, M.; Skurzyński, J.; Jary, Z. Lithological indicators of loess sedimentation of SW Poland. Contemp. Trends Geosci. 2017, 6, 94-111. [CrossRef]

13. Johansson, A.E. Single-Grain Zircon U-Pb Dating and Magnetic Susceptibility of Polish Loess to Determine Late Quaternary Dust Provenance and Paleoclimate. Master's Thesis, Uppsala University, Uppsala, Sweden, 2018; p. 84.

14. Pye, K. The nature, origin and accumulation of loess. Quat. Sci. Rev. 1995, 14, 653-667. [CrossRef]

15. Buggle, B.; Glaser, B.; Hambach, U.; Gerasimenk, N.; Markovic, S. An evaluation of geochemical weathering indices in loess-paleosol studies. Quat. Int. 2011, 240, 12-21. [CrossRef]

16. Liang, L.; Sun, Y.; Beets, C.J.; Prins, M.A.; Wu, F.; Vandenberghe, J. Impacts of grain size sorting and chemical weathering on the geochemistry of Jingyuan loess in the northwestern Chinese Loess Plateau. J. Asian Earth Sci. 2013, 69, 177-184. [CrossRef]

17. Halicki, B. Dyluwialne zlodowacenie północnych stoków Tatr. Spraw. Państwowego Inst. Geol. 1930, 5, 377-534.

18. Klimaszewski, M. Karpaty wewnętrzne. In Geomorfologia Polski; Polish Scientific Publishers (PWN): Warszawa, Poland, 1972; Volume 1, pp. 25-52.

19. Oszast, J.; Stuchlik, L. The Neogene vegetation of the Podhale (West Carpathians, Poland). Acta Palaeobot. $1977,18,45-86$.

20. Birkenmajer, K. Neogene to Early Pleistocene subsidence close to the Pieniny Klippen Belt. Polish Carpathians. Studia Geomorphol. Carpato-Balc. Krakow 1978, 12, 17-28.

21. Watycha, L. Quaternary formations in bore hole Wróblówka, Podhale region. Kwart. Geol. 1973, 17, 335-347, (In Polish with English summary).

22. Watycha, L. Objaśnienia do szczegółowej mapy geologicznej polski 1:50 000. Arkusz Jabłonka (1047). Inst. Geol. 1997, 1, 30-34.

23. Watycha, L. Objaśnienia do szczegółowej mapy geologicznej polski 1:50 000. Arkusz Czarny Dunajec (1048). Inst. Geol. 1977, 1, 1-102.

24. Baumgart-Kotarba, M. Channel and terrace formation due to differentia tectonic movements (with the eastern Podhale Basin as example). Geogr. Stud. IG Pan 1983, 145, 1-133, (In Polish with English summary).

25. Baumgart-Kotarba, $M$. The geomorphological evolution of the intramontane Orawa Basin associated with neotectonic movements (Polish Carpathians). Studia Geomorphol. Carpato-Balc. 1991-1992, 25, 3-28, (In Polish with English summary). 
26. Kukulak, J. Weathering of gravels in the Czarny Dunajec alluvial cone in Podhale Polish Carpathians. Quastiones Geogr. 2000, 21, 69-78.

27. Baumgart-Kotarba, M.; Marcak, H.; Márton, E. Rotation along transverse transforming Orava strike-slip fault: Based on geomorphological, geophysical and paleomagnetic data (Western Carpathians). Geol. Carpath. 2004, 55, 219-226.

28. Tokarski, A.K.; Márton, E.; Świerczewska, A.; Fheed, A.; Zasadni, J.; Kukulak, J. Neotectonic rotations in the Orava-Nowy Targ Intramontane Basin (Western Carpathians): An integrated palaeomagnetic and fractured clasts study. Tectonophysics 2016, 685, 35-43. [CrossRef]

29. Lindner, L.; Dzierżek, J.; Marciniak, B.; Nitychoruk, J. Outline of quaternaryglaciations in the tatra mountains: Their development, age and limits. Geol. Q. 2003, 47, 269-280.

30. Olszak, J.; Kukulak, J.; Alexanderson, H. Revision of river terrace geochronology in the Orawa-Nowy Targ Depression, south Poland: Insights from OSL dating. Proc. Geol. Assoc. 2016, 127, 595-605. [CrossRef]

31. Olszak, J.; Kukulak, J.; Alexanderson, H. Climate control on alluvial sediment storage in the northern foreland of the Tatra Mountains since the late Pleistocene. Quat. Res. 2019, 91, 520-532. [CrossRef]

32. Watycha, L. The neogene of the orava-nowy targ basin. Kwart. Geol. 1976, 20, 575-586, (In Polish with English summary).

33. Chmielowska, D.; Woronko, B. A source of loess-like deposits and their attendant palaeoenvironment-Orava Basin, Western Carpathian Mountains, S Poland. Aeolian Res. 2019, 38, 60-76. [CrossRef]

34. Książkiewicz, M. Budowa geologiczna Polski. T. IV. Tektonika, cz. 3. Karpaty. Publ. House Wydaw. Geol. 1972, 3, 1-228.

35. Pomianowski, P. Structure of the Orava Basin in the light of selected geophysical data. Ann. Soc. Geol. Pol. 1995, 64, 67-80, (In Polish, English summary).

36. Pomianowski, P. Tectonics of the orava-nowy targ basin-Results of the combined analysis of the gravity and geoelectrical data. Przeglad Geol. 2003, 51, 498-506, (In Polish with English summary).

37. Golonka, J.; Aleksandrowski, P.; Aubrecht, M.; Chowaniec, J.; Chrustek, M.; Cieszkowski, M.; Florek, R.; Gawęda, A.; Jarosiński, M.; Kępińska, B.; et al. Orava deep drilling project and the post paleogene tectonics of the carpathians. Ann. Soc. Geol. Pol. 2005, 75, 211-248.

38. Łoziński, M.; Ziółkowski, P.; Wysocka, A. Tectono-sedimentary analysis using the anisotropy of magnetic susceptibility: A study of the terrestrial and freshwater Neogene of the Orava Basin. Geol. Carpathica 2017, 68, 479-500. [CrossRef]

39. Bac-Moszaszwili, M. Structure of the western termination of the Tatra massif. Ann. Soc. Geol. Pol. 1993, 63, 167-193, (In Polish with English summary).

40. Bac-Moszaszwili, M. Diversity of neogene and quaternary tectonic movements in the tatra mountains. Folia Quat. 1995, 66, 131-144.

41. Baumgart-Kotarba, M. On origin and age of the Orawa Basin, West Carpathians. Studia Gomorphologica Carpatho-Balc. 1996, 30, 101-116.

42. Baumgart-Kotarba, M.; Král, J. Young tectonic uplift of the Tatra Mts.(fission track data and geomorphological arguments). Proceedings of XVII. Congress of Carpathian-Balkan Geological Association. Geol. Carpathica, Spec. Issue 2002, 53.

43. Struska, M. Neogeńsko-czwartorzędowy rozwój strukturalny Kotliny Orawskiej w świetle badań geologicznych, geomorfologicznych oraz teledetekcyjnych. (Ph.D. thesis). Arch. Wydziału Geol. Geofiz. i Ochr. Środowiska AGH 2008, 1-149.

44. Tokarski, A.; Świerczewska, A.; Zuchiewicz, W.; Starek, D.; Fodor, L. Quaternary exhumation of the Carpathians: A record from the Orava-Nowy Targ Intramontane Basin, Western Carpathians (Poland and Slovakia). Geol. Carpathica 2012, 63, 257-266. [CrossRef]

45. Lisiecki, L.E.; Raymo, M.E. A Pliocene-Pleistocene stack of 57 globally distributed benthic $\delta 18 \mathrm{O}$ records. Paleoceanography 2005, 20. [CrossRef]

46. Habbe, K.A.; Ellwanger, D.; Becker-Haumann, R. Stratigraphische begriffe für das quartär des süddeutschen alpenvorlandes. EG Quat. Sci. J. 2007, 56, 66-83. [CrossRef]

47. Doppler, D.; Kroemer, E.; Roegner, K.; Wallner, J.; Jerz, H.; Grottenthaler, W. Quaternary stratigraphy of Southern Bavaria. Quatern. Sci. J. 2011, 60, 329-365. [CrossRef]

48. Kotański, Z. The position of the tara mountains in the western carpathians. Przeglad Geol. 1979, 27, 359-369, (In Polish with English summary). 
49. Piotrowska, K.; Danel, W.; Iwanow, A.; Gaździcka, E.; Rączkowski, W.; Bezák, V.; Maglay, J.; Polák, M.; Kohút, M.; Gross, P. Budowa geologiczna. Atlas Tatr. Przyr. Nieożywiona 2015, IV.1.

50. Gołab, J. On the geology of the Western Podhale flysch area. Biul. Inst. Geol. 1959, 149, 225-240.

51. Oszczypko, N.; Ślączka, A.; Żytko, K. Regionalizacja tektoniczna Polski: Karpaty zewnętrzne i zapadlisko przedkarpackie. Przegląd Geol. 2008, 56, 927-935.

52. Świerczewska, A.; Tokarski, A.K. Deformation bands and the history of folding in the Magura nappe, Western Outer Carpathians (Poland). Tectonophysics 1998, 297, 73-90. [CrossRef]

53. Cieszkowski, M.; Oszczypko, N. Development of sediments of the Magura Nappe in the peri-Klippen zone, Carpathians. Przeglad Geol. 1986, 6, 327-334, (In Polish with English summary).

54. Oszczypko, N.; Oszczypko-Clowes, M. Geological structure and evolution of the Pieniny Klippen Belt to the east of the Dunajec River-A new approach (Western Outer Carpathians, Poland). Geol. Q. 2014, 58, 737-758.

55. Wysocka, A.; Łoziński, M.; Śmigielski, M.; Czarniecka, U.; Bojanowski, M. New data on the age of the sedimentary infill of the Orava-Nowy Targ Basin-A case study of the Bystry Stream succession (Middle/Upper Miocene, Western Carpathians). Geol. Q. 2018, 62, 327-343. [CrossRef]

56. Plewa, K. An analysis of gravel covers in the Domański Wierch Fan. Folia Geogr. Ser. Geogr. Phys. 1969, 3, 101-115, (In Polish, English summary).

57. Gotkiewicz, M.; Szaflarski, J. Dyluwjalne i predyluwjalne poziomy dolinne na Orawie. Warszawa 1934, 2, 187-226.

58. Udden, J.A. Mechanical composition of clastic sediments. Bull. Geol. Soc. Am. 1914, 25, 655-744. [CrossRef]

59. Wentworth, C.K. A scale of grade and class terms for clastic sediments. J. Geol. 1922, 30, 377-392. [CrossRef]

60. Chmielowska, D. Polygenesis of Loamy Deposits on Glaciofluvial Fans of Czarny Dunajec River in Orava Basin. Ph.D. Thesis, Pedagogical University of Krakow, Krakow, Poland, 2016; p. 206.

61. Obidowicz, A. The Puścizna Rękowiańska raised bog. In Lateglacial and Holocene Environmental Changes Vistula Basin, Excursion Guide Book-Symposium; Publishing House Wydawnictwa Akademii Górniczo-Hutniczej: Cracow, Poland, 1988; pp. 87-90.

62. Obidowicz, A. Eine pollenanalytische und moorkundliche studie zur vegetations-Geschichte des podhale gebietes (West-Karpaten). Acta Palaeobot. 1990, 30, 147-219.

63. Folk, R.L.; Ward, W.C. Brazos River bar [Texas]; a study in the significance of grain size parameters. J. Sediment. Res. 1957, 27, 3-26. [CrossRef]

64. Blott, S.; Pye, K. Gradistat: a grain size distribution and statistics package for the analysis of unconsolidated sediments. Earth Surf. Process. Landf. 2001, 26, 1237-1248. [CrossRef]

65. Galehouse, J.S. Point counting. In Procedures in Sedimentary Petrology; Carver, R.E., Ed.; Wiley Interscience: New York, NY, USA, 1971; pp. 385-407.

66. Powers, M.C. A new roundness scale for sedimentary particles. J. Sediment. Res. 1953, 23, 117-119. [CrossRef]

67. Henry, D.J.; Guidotti, C.V. Tourmaline as a petrogenetic indicator mineral: An example from the staurolite-grade metapelites of NW Maine. Am. Mineral. 1985, 70, 1-15.

68. Henry, D.J.; Novák, M.; Hawthorne, F.C.; Ertl, A.; Dutrow, B.L.; Uher, P.; Pezzotta, F. Nomenclature of the tourmaline-supergroup minerals. Am. Mineral. 2011, 96, 895-913. [CrossRef]

69. Locock, A.J. An Excel spreadsheet to classify chemical analyses of amphiboles following the IMA 2012 recommendations. Comput. E Geosci. 2014, 62, 1-11.

70. Hawthorne, F.C.; Oberti, R.; Harlow, G.E.; Maresch, W.V.; Martin, R.F.; Schumacher, J.C.; Welch, M.D. IMA report, nomenclature of the amphibole supergroup. Am. Mineral. 2012, 97, 2031-2048. [CrossRef]

71. Tolosana-Delgado, R; Eynatten, H; Krippner, A; Meinhold, G. A multivariate discrimination scheme of detrital garnet chemistry for use in sedimentary provenance analysis. Sediment. Geol. 2018, 375, 14-26. [CrossRef]

72. Morton, A.C.; Hallsworth, C.R. Identifying provenance specific features of detrital heavy mineral assemblages in sandstones. Sediment. Geol. 1994, 90, 241-256. [CrossRef]

73. Hubert, J.F. A zircon-tourmaline-rutile maturity index and the interdependance of the composition of heavy mineral assemblages with the gross composition and texture of sandstones. J. Sediment. Petrol. 1962, 32, 440-450.

74. Aubrecht, R.; Meres, Š.; Sykora, M.; Mikuš, T. Provenance of the detrital garnets and spinels from the Albian sediments of the Czorsztyn Unit (Pieniny Klippen Belt, Western Carpathians, Slovakia). Geol. Carpathica 2009, 60, 463-483. [CrossRef] 
75. Méres, Š.; Aubrecht, R.; Gradziński, M.; Sýkora, M. High (ultrahigh) pressure metamorphic terrane rocks as the source of the detrital garnets from the Middle Jurassic sands and sandstones of the Cracow Region (Cracow-Wielun Upland, Poland). Acta Geol. Pol. 2012, 6, 231-245. [CrossRef]

76. Gawęda, A.; Winchester, J.A.; Kozłowski, K.; Narębski, W.; Holland, J.G. Geochemistry and palaeotectonic setting of amphibolites from the Western Tatra Mountains, southern Poland. Geol. J. 2000, 35, 69-85. [CrossRef]

77. Janák, M.; Kahan, S.; Jančula, D. Metamorphism of pelitic rocks and metamorphic zones in SW part of Western Tatra Mts. Crystalline complexes. Geol. Carpathica 1988, 39, 455-488.

78. Janák, M.; O’Brien, P.J.; Hurai, V.; Reutel, C. Metamorphic evolution and fluid composition of garnet-clinopyroxene amphibolites from the Thatra Mountains, Western Carpathians. Lithos 1996, 39, 57-79. [CrossRef]

79. Garzanti, E.; Andò, S.; Vezzoli, G. Grain-size dependence of sediment composition and environmental bias in provenance studies. Earth Planet. Sci. Lett. 2009, 277, 422-432. [CrossRef]

80. Oszczypko, N.; Salata, D. Provenance analyses of the Late Cretaceous-Palaeocene deposits of the Magura Basin (Polish Western Carpathians)-evidence from the heavy minerals study. Acta Geol. Pol. 2005, 55, 237-267.

81. Kovác, M.; Král, J.; Márton, E.; Plašienka, D.; Uher, P. Alpine uplift history of the Central Western Carpathians: Geochronological, paleomagnetic, sedimentary and structural data. Geol. Carpathica 1994, 45, 83-96.

82. Kohút, M.; Sherlock, S.C. Laser microprobe ${ }^{40} \mathrm{Ar}-{ }^{39} \mathrm{Ar}$ analysis of pseudotachylyte and host rocks from the Tatra Mountains, Slovakia: Evidence for Late Paleogene seismic/tectonic activity. Terra Nova 2003, 15, 417-424. [CrossRef]

83. Jurewicz, E. Geodynamic evolution of the Tatra Mts. and the Pieniny Klippen Belt (Western Carpathians): Problems and comments. Acta Geol. Pol. 2005, 55, 295-338.

84. Kohút, M.; Janák, M.; Broska, I.; Majka, J. The Tatra Mts. typical "core mountains" of the Western Carpathians-Their structure and evolution of the crystalline basement. Mineral. Spec. Pap. 2011, 38, 197-210.

85. Janák, M. Variscan uplift of the crystalline basement Tatra Mts. Central Western Carpathians: Evidence from ${ }^{40} \mathrm{Ar} /{ }^{39} \mathrm{Ar}$ laser probe dating of biotite and P-T-t paths. Geol. Carpathica 1994, 45, 293-300.

86. Gawęda, A.; Kozłowski, K. Pressure-temperature-time evolution of metamorphic complex in the Polish part of the Western Tatra Mts. Pol. Tow. Mineral. Pr. Spec. 1996, 7, 20-22.

87. Corfu, F.; Hanchar, J.M.; Kinny, P. Atlas of zircon textures. In Zircon. Reviews in Mineralogy and Geochemistry; Hanchar, J.M., Hoskin, P.W.O., Eds.; Mineralogical Society of America, Geochemical Society: Washington, DC, USA, 2003; Volume 53, pp. 468-500.

88. Smalley, I.; O'Hara-Dhand, K.; Wint, J.; Machalett, B.; Jary, Z.; Jefferson, I. Rivers and loess: The signifcance of long river transportation in the complex eventsequence approach to loess deposit formation. Quat. Int. 2009, 198, 7-18. [CrossRef]

89. Vandenberghe, J. Grain size of fne-grained windblown sediment: A powerful proxy for process identifcation. Earth-Sci. Rev. 2013, 121, 18-30. [CrossRef]

90. Kłapyta, P.; Zasadni, J.; Pociask-Karteczka, J.; Gajda, A.; Franczak, P. Late Glacial and Holocene paleoenvironmental records in the Tatra Mountains, East-Central Europe, based on lake, peat bog and colluvial sedimentary data: A summary review. Quat. Int. 2016, 415, 126-144. [CrossRef]

(C) 2020 by the authors. Licensee MDPI, Basel, Switzerland. This article is an open access article distributed under the terms and conditions of the Creative Commons Attribution (CC BY) license (http://creativecommons.org/licenses/by/4.0/). 